\title{
Dilution Versus Unfair Advantage: Myths and Realities
}

\author{
Dima Basma
}

Accepted: 13 September 2021 / Published online: 21 October 2021

(C) The Author(s) 2021

\begin{abstract}
Recent developments in the commercial marketplace have rendered the classification of trademarks as mere tools for remedying information asymmetry and assuring quality inaccurate. The value of trademarks as communicative tools has increased, and they are now being used by their owners to transmit images, value propositions and associations to consumers in order to drive purchases. However, while this new function of trademarks is a reality that can hardly be ignored, finding a convincing normative justification to legally support its integration into the trademark system remains problematic. Thus, building on the normative justifications advanced by the European Union (EU) to justify extended trademark protection, this paper evaluates the dilutive harm theory, including blurring and tarnishment, in addition to the misappropriation rationale. The paper reviews EU case law in this respect and sheds light on the current muddled state of law in dealing with extended trademark protection. Based on this analysis, the paper offers a workable framework which can be utilized by courts to address cases related to modern trademark functions. The paper concludes that the misappropriation rationale should be the principal ground for extending trademark protection, and that harm resulting from blurring and tarnishment should act as an ancillary for misappropriation claims.
\end{abstract}

Keywords Dilution · Blurring · Tarnishment - Unfair advantage · Economic harm · Free-riding 


\section{Introduction}

Recent developments in the commercial marketplace have rendered the classification of trademarks as mere tools for remedying information asymmetry and assuring quality inaccurate. The value of trademarks as strong communicative tools has increased. With the help of extensive marketing investments, trademarks are now being used by their owners to signal images, value propositions and associations in order to drive purchases. Corporations use trademarks to create and foster social relationships with consumers, who accordingly become loyal to any product originating from this company. Simultaneously, consumers utilize images associated with trademarks within the social environment for the purpose of selfsatisfaction (inward communication) or to create dialogues with other members of the public (outward communication).

In order to foster the communicative role of trademarks, companies tend to invest in promoting the advertising value of trademarks to increase their persuasive impact. ${ }^{1}$ This evolving role of trademarks has prompted a reconsideration of the traditional system for trademark protection in Europe. But the task is far from straightforward. According to a plethora of jurists, although the new function of trademarks is a reality that can hardly be ignored, finding a normative justification to legally support its integration into the trademark system remains difficult, ${ }^{2}$ and in the absence of a convincing justification, trademark law may be transformed into an arbitrary mode of protection based on pure legal realism. ${ }^{3}$

As a result of this controversy, the modernization of the European trademark system was preceded by a stage of debate and conflict among Member States, underpinned by the divergent attitudes towards unfair competition. ${ }^{4}$ Eventually, Art. 5(2) of Trade Marks Directive (TMD) 1989, mirroring Art. 10(2)(c) of the current TMD, was introduced. ${ }^{5}$ Broadly, the Article allowed for the protection of trademarks with a reputation against harm to reputation, distinctiveness and unfair advantage. ${ }^{6}$ Despite the apparent success in merging the conflicting attitudes of Member States under Art. 10(2)(c), matters are far from resolved. The language of the Article is obscure and the normative justifications advanced in this respect continue to be resisted, criticized and applied inconsistently within national courts.

Regrettably, European case law dealing with modern trademark protection has only touched on the surface of these justifications, often relying on incomprehensible abstract notions. Simultaneously, in analyzing modern trademark cases, EU courts have addressed these justifications independently, failing to incorporate the

\footnotetext{
${ }^{1}$ Brown (1948), p. 1116.

${ }^{2}$ Some academics argue that finding a theoretical justification for intellectual property protection is insignificant. See Rahmatian (2005), p. 374. In contrast see Fisher, in Munzer (ed) (2001), pp. 168-193.

${ }^{3}$ Chronopoulos (2011), p. 554. Legal realists tend to view legal reasoning as being independent from moral and political discourse. For a general overview see Alexander (2014).

${ }^{4}$ Debates amplified the given resistance of some European Member States to adopt moral-based justifications for trademark protection.

5 Art. 5(2) of Council Directive (EU) 2008/95 EC, mirroring Art. 10(2)(c) Council Directive (EU) $2015 / 2436$.

${ }^{6}$ Ibid.
} 
obvious link between these rationales into their reasoning. Hence, this paper has two main objectives: firstly, to offer an in-depth analysis of these justifications and their shortcomings, taking into account modern theories on consumer behavior and using the luxury fashion industry as an analytical tool; and secondly, to address the interfaces between these justifications. Based on this analysis, the paper aims to offer an integrative, workable framework which can be utilized by courts to analyze trademark cases emerging under Art. 10(2)(c) of the TMD.

The choice of the luxury fashion industry as an analytical tool is premised on the fact that, especially within this industry, consumers receive in addition to a tangible product an intangible added value. Practically, the extended protection offered under Art. 10(2)(c) aims mainly to protect this intangible added value. This renders this industry a perfect reference point for a more constructive evaluation of the dilution and unfair advantage rationales, both of which drive modern trademark protection within the EU.

\section{Basics}

The evolution of trademarks from mere source identification tools into instruments of prominent communicative value has prompted the introduction of a revolutionary Article into the European (EU) TMD, namely Art. 5(2) of the earlier TMD. ${ }^{7}$ This Article, which was optional in its initial formulation, has become binding under the corresponding Art. 10(2)(c) of the TMD 2015. ${ }^{8}$

According to Art. 10(2)(c):

Without prejudice to the rights of proprietors acquired before the filing date or the priority date of the registered trade mark, the proprietor of that registered trade mark shall be entitled to prevent all third parties not having his consent from using in the course of trade, in relation to goods or services, any sign where:...

the sign is identical with, or similar to, the trade mark irrespective of whether it is used in relation to goods or services which are identical with, similar to, or not similar to, those for which the trade mark is registered, where the latter has a reputation in the Member State and where use of that sign without due cause takes unfair advantage of, or is detrimental to, the distinctive character or the repute of the trade mark. ${ }^{9}$

\footnotetext{
7 See Laan (2012).

${ }^{8}$ Directive 2008/95/EC17 of 22 October 2008 to approximate the laws of the Member States relating to trad marks, which codified Directive 89/104/EEC of 21 December 1988 (as amended Community Trade Marks (CTMR). However, as a result of the reform process, the new European Trade Mark Directive 2015/2436 of 16 December 2015 to approximate the laws of the Member States relating to trade marks (Recast) entered into force on 15 January 2016. In relation to extended trademark protection, Art. 10(2)(c) of the Trade Mark Directive 2015/2436 mirrors Art. 5(2) of Directive 2008/95/EC17.
}

9 Art. 10(2)(c) of Trade Mark Directive 2015/2436 (2015). 
The wording of the Article reflects a derogation from the confusion-based interpretation of trademarks. ${ }^{10}$ Based on this Article, instigating a successful claim requires the fulfilment of six conditions:

1. That the trademark is used in the course of trade in relation to goods and services. ${ }^{11}$

2. That the mark used is identical or similar to an earlier mark. ${ }^{12}$

3. That the mark is used on goods or services which are similar or not similar to those for which the earlier mark is registered.

4. That the earlier mark has a reputation. ${ }^{13}$

5. That the mark is used without due cause. ${ }^{14}$

6. That the trademark use "takes unfair advantage of, or is detrimental to, the distinctive character or the repute of the trade mark".

Whilst each of these conditions has engendered theoretical and judicial uncertainty, ${ }^{15}$ this paper is concerned primarily with the sixth condition. Namely, whether a trademark use takes unfair advantage of or is detrimental to the distinctive character or the repute of a senior trademark. An initial analysis of this condition reveals that it is underpinned by two legal theories. Firstly, the Article protects trademark owners against misappropriation of their marks, ${ }^{16}$ as evidenced by the use of the term "unfair advantage". ${ }^{17}$ Secondly, reference to the terms "distinctive character" and "repute of a mark" reflect an intention to protect the selling power of the mark, ${ }^{18}$ often referred to as dilution. ${ }^{19}$ So, although the term dilution is not explicitly used in the wording of Art. $10(2)(\mathrm{c}),{ }^{20}$ the language of the Article closely resembles the anti-dilution provisions previously existing in Benelux countries. ${ }^{21}$ In

\footnotetext{
${ }^{10}$ See C-206/01 Arsenal Football Club v. Matthew Reed [2002] E.T.M.R. 19, C-487/07 L'Oréal SA v. Bellure NV [2009] ECLI 378, C-323/09 Interflora v. Marks and Spencer [2011] ECLI:EU:C:2011:604.

11 See C-206/01 Arsenal Football Club v. Matthew Reed (supra note 10), para. 18. Opinion of AG Ruiz Colomer. Also see C-17/06 Celine SARL v. Celine SA [2006] ECR I-0704.

12 See C-102/07 Adidas and Adidas Benelux [2008] ECR I-0000 (“Adidas II"), C-228/03 Gillette Company v. Gillette Group Finland [2005] ECR I-2337, para. 43.

13 See C-375/97 General Motors Corp v. Yplon SA [1999] ECR I-5421, para. 25.

14 R-283/1993-3 Hollywood S.A.S. v. Souza Cruz S.A. [2002] E.T.M.R. 705, para. 66; British Sky Broadcasting Group Plc v. Microsoft Corp [2013] EWHC 1826 (Ch).

15 Basma (2016), pp. 328-330.

16 EUIPO (2020), part 3.4.3.1), p. 48.

17 In contrast, see Sec. 43 of the Lanham Act (1943), in which there is no explicit misappropriation provision.

18 Griffiths (2007), p. 326.

19 Griffiths (2001), p. 356.

20 The term dilution was first used in 2003 in the case of C-408/01 Adidas-Salomon AG [2003] E.T.M.R.

91, Opinion of AG Jacobs, paras. 36-40.

21 See Sec. 13 of Benelux Trademark Act (1978).
} 
this sense, Benelux trademark law has had a clear influence on the drafting of Art. $10(2)(\mathrm{c}) .^{22}$

Although Art. 10(2)(c) attempted to clarify the justifications that could be advanced for the protection of modern trademark functions, three aspects continue to raise concerns. Firstly, whether these justifications are convincing and sufficient. Secondly, whether the EU courts are implementing them in a logical and coherent manner. Finally, whether these justifications should be addressed separately or collectively. Thus, the following section will start by exploring the theory of dilution and will analyze its effectiveness in capturing cases emerging in the context of Art. 10(2)(c).

\section{Dilutive Harm}

\subsection{Background}

The first justification advanced for the protection of the modern functions under Art. $10(2)(c)$ is that failure to grant trademark owners extended forms of legal protection would result in dilutive harm. ${ }^{23}$ Dilution is defined as the "gradual whittling away of a trademark's distinctive capabilities". ${ }^{24}$ Under this view, non-confusing uses of famous marks can dilute their selling power due to cumulative harm. This can eventually lead to loss of distinctive character and thus the demise of the mark. ${ }^{25}$ Protection against dilution supposedly ensures that trademark owners will be able to maintain an association in the mind of the consumers between their marks and their products. $^{26}$ The dilutive harm theory proposes that the use of a mark on an unrelated product leads to the impairment of the trademark's strength through either blurring of the distinctive character of the mark or through tarnishing it with an unsavory association. $^{27}$

Such explanation of dilutive harm, which has been accepted in both the $\mathrm{US}^{28}$ and in Europe, ${ }^{29}$ can be criticized for being vaguely constructed. Accordingly, it is often

\footnotetext{
${ }^{22}$ Robinson et al. (2013), p. 23 by reference to Neuberger LJ's opinion. Although the US concept of dilution is useful it should not be blindly rewritten. See Premier Brands UK v. Typhoon Europe Ltd [2000] E.T.M.R. 1071, para. 1092.

23 See generally, Schechter (1927).

24 Ibid., p. 825. Also see US case of Allied Maintenance Corp. v. Allied Mechanical Trades Inc. 369 N.E.2d 1162 (N.Y. 1977), p. 1165 where dilution was defined as "cancer-like growth which feeds upon the reputation of an established distinctive trademark".

25 This view was embraced in a large number of particularly US cases. See ibid., p. 1164.

26 Corresponding to the CJEU reasoning in the case Interflora $v$. Marks and Spencer (supra note 10).

27 Prager (1996), pp. 123-124.

28 In the US case Mosely v. Victoria Secret Catalogue 537 U.S. 418 (2003), the courts quoted Schechter's contention that the preservation of the uniqueness of a trademark should constitute the only basis for trademark protection.

29 Although LJ Sharpston in the case of Intel acknowledged that its duty was to interpret the wording of the Directive rather than Schechter's rational basis. However, Schechter's influence remains clear. C-253/ 07 Intel Corporation Inc. v. CPM United Kingdom Limited [2008] ECR I-08823, para. 10.
} 
argued that reference to the need to preserve the uniqueness of a mark is merely an attempt to satisfy legal realists ${ }^{30}$ by diverting their attention from the misappropriation rationale which actually underlies the theory. This constitutes a more compelling reason to consider the dilution theory afresh. Thus, the prospective analysis will evaluate and challenge the CJEU approach towards blurring and tarnishment. $^{31}$

\subsection{Blurring}

Blurring is often explained in light of the associative network theory. Based on this theory, human memory is comprised of nodes. These nodes link certain product categories in the mind of consumers with particular trademarks. ${ }^{32}$ When a new product is introduced under the same brand name, the ability of a human brain to evoke the original product would be weakened due to the later use. ${ }^{33}$ Gradually, the earlier mark that was once able to arouse an immediate association with a particular product will lose this ability. ${ }^{34}$ Ultimately, if the same sign is used for multiple products and services, the average consumer will cease to link the mark with the original goods to which it was associated. ${ }^{35}$ This is referred to as "dilutive harm", 36 which decreases the selling power of the mark. Initially, the use may not have a diluting impact, however "it may trigger further acts that would disperse the identity of the mark thus diluting it". This is referred to as the avalanche effect. ${ }^{37}$ Based on this, proponents of blurring argue that that the law should interfere to protect trademark owners against the risk of dispersion of their identity and dissociation that may result from uncontrolled trademark use. Blurring, despite its ostensive attractiveness, has inherent contextual complexities. In this regard, it is useful to commence by analyzing existing EU case law.

\subsubsection{Blurring in Europe}

Prior to the introduction of Art. 10(2)(c), blurring was indirectly recognized in the judgments of several EU national courts. In the UK case of Taittinger, Lord Bingham noted that the reputation a Champagne brand derives not only from the quality of their wine and its glamorous association, but also from the exclusiveness of the description. In the words of Lord Bingham, "Any product which is not Champagne but is allowed to describe itself as such must inevitably erode the exclusiveness of the description Champagne and so cause Taittinger damage of an

\footnotetext{
${ }^{30}$ Bone describes dilution as an atypical example of the legal realism project. See Bone (2008), p. 471.

31 Rierson notes that tarnishment has more intuitive appeal than blurring; however, both can be criticized. Rierson (2012), p. 246. Also see Tran (2002), p. 1 for a critique on the concept of tarnishment.

32 See Anderson (1983).

33 Swann (2002), pp. 607-608. Also see Morrin et al. (2006), pp. 248-249.

34 See Intel Corporation (supra note 29). Also see Klieger (1997), pp. 789, 801.

35 EUIPO (supra note 16), part 3.4.3.2), p. 38.

36 Desai et al. (2015), p. 212.

37 EUIPO (supra note 16), part 3.4.3.2), p. 57
} 
insidious but serious kind." 38 However, reference to such type of harm was incidental and mainly in the context of confusion-based rationales.

Subsequent to the introduction of Art. 10(2)(c), reference to blurring as a separate cause of action became a regular occurrence. An interesting starting point to evaluate blurring in Europe under Art. 10(2)(c) is the case of Premier Brands, in which Neuberger J. concluded that significant damage to the advertising function of the first mark was necessary for a plea of blurring to be successful. ${ }^{39}$ The vague nature of this statement generated a real risk that blurring would develop into a catch-all cause of action.

However, subsequent CJEU decisions attempted to eliminate such risk by developing stringent - perhaps unfeasible - criteria for filing successful blurring claims. ${ }^{40}$ In both Intel and General Motors, it was remarked that blurring results in the dispersion of identity of the senior mark. Particularly, it will destroy its ability to trigger an immediate association in the mind of the relevant public. ${ }^{41}$ The relevant public comprises the average consumers of the goods and services for which the mark is registered, who are reasonably well-informed, reasonably observant and circumspect. ${ }^{42}$ Courts noted that demonstrating that dispersion of identity actually occurred should be proven through credible evidence. ${ }^{43}$

In Intel, AG Sharpston took a step further in noting that distinctiveness relates to the traditional view of trademark law, in particular trademarks' essential function. ${ }^{44}$ Courts proposed that a successful blurring claim requires proof that there is actual, or a serious foreseeable risk of, change in the consumer's economic behavior. Despite the absence of clear guidance on this key evidentiary requirement, it is inferable that establishing a successful blurring claim requires direct evidence. ${ }^{45}$ The impression given by courts is that the evidence needs to be concrete and nonhypothetical. $^{46}$

This point was reiterated in the case of Environmental Manufacturing. ${ }^{47}$ The GC in this case rejected the appellant's claim that change in economic behavior may be logically deduced from the strength of the senior mark's reputation or the similarity

\footnotetext{
38 Taittinger v. Allbev Ltd. [1993] F.S.R. 641. In this case distinctiveness was recognized only if accompanied with misrepresentation. Also see C-39/97 Canon Kabushiki Kaisha v. MGM [1999] R.P.C. 117, paras. 132-133.

39 Premier Brands (supra note 22). In T-67/04 Spa Monopole, Compagnie Fermière de Spa SA/NV v. OHIM [2005] ECLI: EU: T: 2005, para. 44, it was noted that commonly used words are less likely to be subject to blurring. Also see T-215/03 SILGA AG v. OHIM [2007] ECR-II-00711.

40 General Motors (supra note 13), Intel Corporation (supra note 29).

41 Ibid.

42 Ibid.

43 Ibid.

44 Intel Corporation Inc (supra note 29), Opinion of AG Sharpston. Also see Fhima (2011), p. 328.

45 This is contrary to the reputation requirement, in which indirect evidence about the state of mind of consumers would suffice.

46 Basma (supra note 15), pp. 201-210. Also see generally Sakulin (2010).

47 T-570/10 RENV Environmental Manufacturing v. Office for Harmonization in the Internal Market (OHIM) [2015] ECLI:EU:T:2015:76.
} 
between the senior and the junior mark. ${ }^{48}$ Thus, courts imposed a high threshold for proving blurring. The objective of this approach was the prohibition of economic operators improperly appropriating certain signs. ${ }^{49}$ According to Gielen, in setting high standards, the CJEU intended to warn against the premature establishment of detriment to distinctiveness. ${ }^{50}$ Practically, in most cases post Intel, claimants failed to adduce evidence for such change. ${ }^{51}$

The application of the change in economic behavior requirement by national courts also revealed inconsistencies. Practically, this is predictable given the imprecise nature of the change in economic behavior criteria advanced by the CJEU. In Sky-care, the court noted that although there was no evidence of change in economic behavior, the link between the junior and the senior mark is bound to lead to "blurring" of the original mark, such as to weaken its ability to serve as a badge of origin for email services. ${ }^{52}$ By inference, courts found change in the economic behavior. ${ }^{53}$ In the cases of Sky kick ${ }^{54}$ and Natural Instinct, ${ }^{55}$ relevant UK courts deduced the existence of change in economic behavior by reference to evidence provided by the claimant on the existence of confusion. Recently, in the case Planetart $L L C,{ }^{56}$ the UK High Court declared that change in economic behavior could be proven by providing evidence that evasive action was, or ought to be, taken by the claimant to re-establish the mark's distinctive character.

The preceding analysis exposes the current disordered state of law in addressing blurring claims. With the objective of avoiding opening a floodgate to a large number of claims, the CJEU introduced the "change in economic behavior requirement". Equivocally, no elaboration on the type of evidence that needs to be adduced was provided. This led to discrepancy in the application of this requirement under national law. To remedy this situation, one might instinctively argue that the CJEU and other relevant bodies ${ }^{57}$ need to provide comprehensive guidance on this matter. However, any guidance would only be useful if the change, or potential change, in economic behavior could be proven definitively, a point which the paper argues against. ${ }^{58}$ In fact, the paper takes a step further by arguing that irrespective of the test the CJEU chooses to adopt, no definitive evidence for blurring could be provided. Given the lack of such evidence, the paper proposes that blurring as a

\footnotetext{
48 T-570/10 Environmental Manufacturing v. Office for Harmonization in the Internal Market (OHIM) [2012] E.T.M.R. 54.

49 Environmental Manufacturing (supra note 47).

50 Gielen (2014), p. 701.

51 R-657/2009 Bambuddha v. Buddha Bar [2010]; R-403/2008-1 Emotions Coffe Cola v. Coca Cola et al [2009].

52 Skyscape Cloud Services Ltd v. Sky Plc [2016] F.S.R. 5, para. 16.

53 Ibid., para. 66.

54 Sky Plc v. Sky Kick UK Ltd [2018] EWHC 166 (Ch).

55 Natural Instinct Ltd v. Natures Menu Ltd [2020] E.T.M.R. 34.

56 PlanetArt LLC v. Photobox Ltd [2020] E.T.M.R. 35.

57 E.g. EUIPO.

58 See pp. 9-11.
} 
separate cause of action lacks convincing justification. ${ }^{59}$ The subsequent sections highlight the deficiencies of both blurring as a normative justification for trademark protection and the change in economic behavior requirement currently upheld by the CJEU.

\subsubsection{Evaluating Blurring}

The practical validity of blurring as a rationale for trademark protection has been highly contested due to the ambiguous characteristics of dilutive harm. In particular, it is unclear whether the alleged blurring effect should be measured by reference to decreased sales, to diminishing of the immediate connection between brands and consumers or to the potential change of consumer attitude towards a brand. Scholars have attempted to propose various conceptualizations to characterize the concept of dilution. However, these remain insufficient, as will be proven subsequently.

Preliminarily, it should be noted that since the luxury fashion industry is among the most vulnerable industries to dilutive harm, evaluating the theory from this lens allows a pro-trademark owner analysis of the theory and its rigor, thus reflecting the highest tolerable level of protection that can be rationally advanced. ${ }^{60}$ However, as will be shown, even if analyzed from this perspective, the theory entails a range of limitations which renders its adoption as a separate cause of action problematic.

\subsubsection{Brand Awareness: Brand Recognition and Brand Recall The basic} premise advanced to justify protection against blurring is that multiple uses of a trademark weaken the link between the original mark and the products associated with it. ${ }^{61}$ This, according to the literature, may engender one of the following effects: proliferation of associations leading to increased search costs, economic harm due to decreased sales or loss of selling power due to loss of exclusivity. Problematically, all of these supposed effects are highly speculative, as will be shown.

Brand Recognition The first assumed effect of blurring is the proliferation of associations which might either disable or weaken brand recognition or alternatively lengthen the process of brand recalling, by reference to Aaker's brand awareness model. $^{62}$

Brand recognition refers to the ability of consumers to identify a product and its features after being exposed to some visual cues, including trademarks. ${ }^{63}$ It is alleged that when an existing mark is used on new products, consumers start associating new meanings with this existing mark, which leads to decreased brand recognition. Some argue that this would jeopardize the capability of the mark to signal specific brand images and associations to consumers. Based on this theory,

\footnotetext{
59 See pp. 8-13.

${ }^{60}$ Kort et al. (2006), p. 1364.

61 Rierson (supra note 31), p. 246.

62 See generally Aaker (1991), Chap. 3. Also see Cho et al. (2019), p. 189.

63 Ibid., Aaker (1991), Chap. 3.
} 
the brand recognition effect which trademarks trigger would be affected. Ultimately, this would lead to blurring.

Problematically, proponents of this view wrongfully assume that words, or marks in our case, may only have one definitive meaning. However, the truth is that linguistically, words comprise several meanings used in varied contexts and their distinctive character remains unchallenged. ${ }^{64}$ Because individuals have the ability to derive meanings from the context, it can be counter-argued that in the case of trademarks, the use of a similar mark in a different context cannot affect brand recognition of the original mark. Indeed, as recent empirical studies show, it would be erroneous to assume that the development of new associations for an existing mark would necessarily weaken existing associations for this mark. ${ }^{65}$ This is particularly true in the context of trademarks, which are usually low-frequency words, not commonly used in everyday language. In such cases, it can be correctly argued that the impact of non-competing uses on brand recognition is almost negligible. ${ }^{66}$ If one is to consider the example of the luxurious Louis Vuitton (LV) being used on car oil, dilution proponents suggest that consumers will eventually cease to associate LV with luxury. However, as confirmed by Beebe et al., this supposed blurring impact cannot be empirically proven when well-known brands are involved, and will anyway disappear when the purchase context is considered. ${ }^{67}$

In a nutshell, consumers who are exposed to an existing mark associated with new products are no less likely to associate the used mark with the original product category. ${ }^{68}$ Even if consumers question the link between LV and the new products initially, such impact is only temporary. ${ }^{69}$ Consumers will eventually be able to distinguish between the meanings associated with the two identical marks, and the communicative ability of the original mark will be able to regain its value. ${ }^{70}$

Brand Recall An emerging line of thought justifies blurring by attributing legal importance to the extra time consumers exert to distinguish between marks in case of multiple uses. ${ }^{71}$ This corresponds to the second element of the brand awareness construct, namely brand recall. According to this view, when a mark is used on two distinct goods, "consumers will have to think harder - incur a higher imagination cost - to recognize the name as the name of the store". ${ }^{72}$ Thus, lack of protection against blurring would burden consumers with extra costs for having to filter from their mind the other uses of trademarks. ${ }^{73}$ On the contrary, protection against

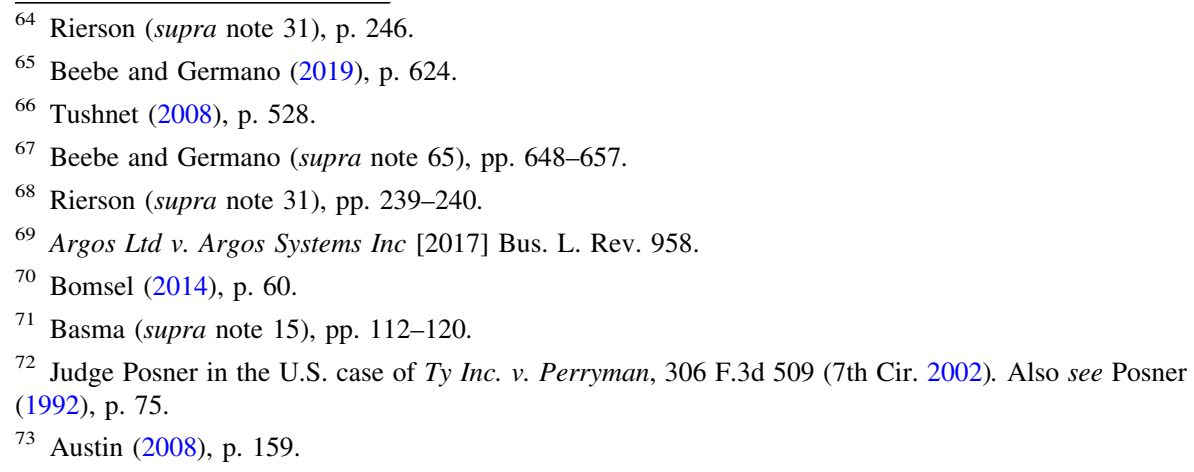


dilution increases efficiency and reduces search costs. ${ }^{74}$ Proponents of this view attempt to revert trademark protection to its original nexus of consumer protection. ${ }^{75}$

Although this view finds some support in cognitive science, ${ }^{76}$ existing empirical data is inconclusive. This rationale thus does not entail sufficient rigor to be transferred into the legal sphere. This point was confirmed by Tushnet, who criticizes the blind reliance on assumptions of increased search costs to justify extended trademark protection. ${ }^{77}$ Morrin and Jacoby's study confirms that, experimentally, blurring (as understood by cognitive science findings) exists; however, it is measured in milliseconds.

More interestingly, those reputable marks which are most vulnerable to freeriding are the least likely to burden consumers with increased consumer search costs in the dilution context. ${ }^{78}$ The question is thus not whether blurring exists numerically, but rather whether it is economically significant enough to be translated into the language of law. The empirical information available to this date shows that proportionally this increase in search cost is insignificant. ${ }^{79}$ In fact, one can take a step further by arguing that there are reasons to think that at least some dilutive uses can reinforce, rather than chip away at, the strength of a mark. Any delay in recognizing which Tiffany's or which Apple a particular use refers to may be compensated for by easier recall of Tiffany's in other contexts. ${ }^{80}$

\subsubsection{Economic Detriment The second, equally unconvincing, argument pro-} posed for the protection against blurring relates to the economic impact of blurring. Generally, this approach conforms to the CJEU's change in economic behavior requirement, which was introduced in Intel. Although the CJEU did not provide sufficient guidance on the meaning of this requirement, it is reasonable to deduce that evidence on economic loss could demonstrate change in economic behavior.

Put simply, the economic impact theory provides that when a brand is being used uncontrollably in different consumer channels, it will lose its clarity in the mind of consumers. ${ }^{81}$ Arguably, within the luxury industry in particular, a brand value derives substantially from the image associated with the products emanating from it. On this premise, companies within these industries will have a strong desire to protect and sustain the image of their brand through investment and advertising. ${ }^{82}$ Overexposure can repulse consumers, discouraging them from consuming the

\footnotetext{
${ }_{74}$ Dogan (2006), p. 105. Also see Tushnet (supra note 66), p. 508.

75 Bird (2006).

76 See Morrin et al. (supra note 33), p. 288.

77 Tushnet (supra note 66), p. 531.

${ }^{78}$ Morrin and Jacoby (2000), p. 288. Also see Beebe and Germanos (supra note 65).

79 Tushnet (supra note 66), p. 528. In contrast see Kang (2005), p. 1489.

${ }^{80}$ Meyers-Levy (1989), p. 197.

${ }^{81}$ See generally, Bomsel (supra note 70), p. 60. Also see Kapferer (2015) arguing that for a brand to remain of dream value to consumers, it has to be rare.

${ }^{82}$ Kay (2006), p. 747; Elliot (1997), p. 287. Elliot notes that the symbolic meanings associated with products operate in two directions, inwardly in constructing self-identity (self-symbolism) and outwardly in constructing the world (social-symbolism).
} 
overexposed branded products. Thus, the utility of the product from the perspective of the consumer will decrease. ${ }^{83}$ Ultimately, the selling power, which is understood in economic terms, will be eroded. ${ }^{84}$ As the level of interactivity between a brand and a product decreases, consumers will easily switch to other brands. ${ }^{85}$ Sales will decrease, and so will the overall profit. Problematically, this argument is based predominantly on a speculative type of harm that may not exist, and may, in all cases, hardly ever be proven definitively.

Two extreme cases from the luxury fashion industry will be used to illustrate the shortcomings of the economic effect argument. Although at first glance these two examples would seem to support the dilutive harm theory, analyzing them through an economic prism yields far more complex results.

The first case is that of Pierre Cardin, a successful fashion designer ${ }^{86}$ whose name was among the most highly recognized in the luxury fashion arena. ${ }^{87}$ Allegedly, Pierre Cardin, who in recognition of the aura of his brand adopted a multiplelicensing strategy, was confronted with a remarkable drop in his revenues, namely subsequent to providing brand licenses on unrelated products (cigarettes, baseball caps, alcoholic beverages). ${ }^{88}$ It has been mistakenly suggested that the loss of uniqueness and the scarcity (i.e. luxury aura) of the brand are particularly responsible for the loss in revenue. ${ }^{89}$ Viewed from a legal perspective, the excessive availability of Pierre Cardin products rendered them less desirable within the luxury consumer market given the blurring effect they were subject to. ${ }^{90}$ The issue is that such claim is assumptive, oversimplistic and most worryingly atomistic. One may correctly counter-argue that the principal cause of such loss is the uncontrolled licensing agreements which were not accompanied with stringent measures of quality control. $^{91}$

Generally, companies such as Pierre Cardin have a goodwill which extends beyond associations with a specific product and includes impressions consumers form about the firm as a whole. ${ }^{92}$ This is referred to as firm goodwill. ${ }^{93}$ It can thus be suggested that the negative associations attached to some low-quality products emanating from Pierre Cardin have transferred to all Pierre Cardin products, thus leading to decreased revenue (corporate branding). ${ }^{94}$ From a trademark perspective,

\footnotetext{
83 Dornis and Wein (2014), pp. 3-4.

84 The economic connotation of the term "selling power" can be inferred from the court's requirement of "change in economic behaviour" as evidence of blurring. See Environmental Manufacturing (supra note 48), para. 54.

85 Okonkwo (2007), p. 301. Also see Reddy and Terblanche (2005). Also see The Fashion Law (2013).

86 Langle (2005), p. 2.

87 Okonkwo (supra note 85), p. 297.

88 Ibid. Also see Reddy and Terblanche (2005), p. 191.

89 Dubois et al. (2011).

90 Som and Blanckaert (2015), p. 111.

91 Calboli (2007), pp. 374-376.

92 Generally see Bone (2006).

93 Ibid.

94 Rao et al. (2004), p. 3.
} 
harm resulting from multiple trademark uses can only occur if the use of a trademark by a third party leads to confusion as to the source of products. The protection against blurring, as already discussed, is independent from confusionbased protection, and practically, for many years, marks have been used concurrently on dissimilar products without evidence of blurring harm. ${ }^{95}$ Even if one is to assume that a certain economic harm can be attributed to excessive availability of Pierre Cardin products within the market place, it is almost impossible to ascertain the degree of harm resulting from blurring. ${ }^{96}$

Another useful example for elaboration is that of Burberry. As a result of their increased advertising and focus on their famous logo, the brand became popular within the "chav generation". 97 According to Jones, the day the "celebrity chav" Daniella Westbrood stepped out in a head-to-toe Burberry outfit, the company's credibility died. ${ }^{98}$ Burberry managed, however, without any legal interference, to reinvent its brand image through a simple branding technique, by simply shifting the brand focus to the iconic products that made the brand famous, focusing on less subtle logo placement. ${ }^{99} \mathrm{~A}$ closer inspection of the Burberry example does not provide definitive answers in relation to the validity of the economic impact of blurring. By reference to the gross profit of Burberry during the periods of the alleged loss of exclusivity (2004-2006) and afterward (2006-2008), it is manifest that economically, there was no material harm. ${ }^{100}$ A possible explanation for this result is that Burberry, which was once sought after by snobs who derive utility from exclusivity, became more attractive for bandwagoners who derive utility from the excessive availability of products. ${ }^{101}$ This process lies at the heart of the business transformations of luxury brands. ${ }^{102}$ In terms of selling power as interpreted by the CJEU, it is difficult to prove with certainty the level of economic harm caused by blurring. ${ }^{103}$ Ultimately, the argument is that mere speculation of harm cannot provide sufficient grounds for expansive trademarks rights (and possible reduction of competition) manifested through an anti-dilution remedy. ${ }^{104}$

Viewed from the angle of financial harm, it can be concluded that the economic behavior requirement proposed by the CJEU is seriously flawed. Analyzing a few extreme cases from within the luxury fashion industry proves that showing that

\footnotetext{
95 For example, see Delta Airlines and Delta Faucets, United Airlines and United Van Lines.

96 Generally see Port (1994), p. 448, Prescott (1997), p. 99.

97 Daily Mail (2008).

98 Cunningham and Cunningham (2014), p. 212.

99 Ostler (2014).

100 Burberry’s Gross Profit in (2004): $£ 391.6$ million; in (2005): $£ 424.2$ million; in 2006: $£ 446.1$ million). See Burberry Group Plc Annual Report and Accounts 2004/05.44, Burberry Group Plc Annual Report and Accounts 2005/06), p. 47.

101 Generally see Akerlof (1980), p. 749; Also see Corneo and Jeanne (1997), p. 333.

102 Kapferer (supra note 81), p. 15.

103 C-252/12 Specsavers International Healthcare Ltd. v. Asda [2013] Bus.L.Rev. 1277, [2013] ECWA Civ. 494. Both the English courts and the CJEU failed to provide additional clarification on what constitutes change in economic behavior.

104 Pattishall (1977), p. 614.
} 
multiple uses have caused financial harm is complicated. Indeed, even if financial loss could be proven, providing sufficient evidence to show that the harm was a direct result of blurring is unattainable. Perhaps this is what prompted national courts, in applying the change in economic behavior requirement, to rely on confusion-based evidence. Despite the fact that relying on confusion-based evidence is not aligned with the objective of the anti-blurring provision, perhaps courts were aware that no other direct evidence could possibly be provided.

\subsubsection{Impact of Blurring on Exclusivity The previous analysis highlighted the} shortcomings of the economic effect rationale of blurring through the prism of financial revenue. However, for proponents of blurring, economic harm extends beyond mere financial revenue. Namely, it is alleged that economic harm caused by blurring accumulates over time and is difficult to measure in the short run. ${ }^{105}$ On this basis, the CJEU recognized the possibility of future harm to distinctive character. ${ }^{106}$ Furthermore, according to this view, "loss of selling power" should be understood as weakening of exclusivity rather than financial loss. ${ }^{107}$ Regrettably, both of the above claims presuppose that the traditional emphasis on exclusivity within the luxury environment is ultimately valid. As the subsequent analysis will show, this allegation is objectionable.

Traditionally, exclusivity and luxury were equated with rarity. In light of the modern changes within the luxury fashion environment, this understanding needs to be re-evaluated. Three particular points should be analyzed: the reinterpretation of luxury within consumer society, the paradox of luxury fashion and the democratization of luxury fashion brands.

Studies on consumers' perception of luxury reveal that exclusivity is only one of many characteristics associated with luxury. Elegance, comfort, style and fashion are all additional factors also associated with luxury. ${ }^{108}$ Thus, associating luxury with exclusivity inaccurately limits the concept of luxury. This brings us to the second point, the paradox of luxury fashion. Whilst exclusivity is a characteristic of luxury, the opposite can be stated about fashion. Fashion refers to the modal or popular style of a particular group at a particular time. ${ }^{109}$ Thus, there is an oxymoron underlying the concept of luxury fashion. This makes it somewhat difficult to expect loss of selling power to emerge from overexposure to marks.

The third, and the most critical, point which further weakens the blurring effect of multi-mark use is the democratization of luxury is general. Luxury consumers who were once defined clearly as head-to-toe "designer-clad" loyalists are now

\footnotetext{
105 See McCarthy (2010), para. 24:120.

106 See Intel Corporation Inc (supra note 29), paras. 38-39.

107 It may be argued that uncontrolled use of a mark could affect the ability of the trademark owner to signal exclusivity. See US case of Hermes Int'l v. Lederer de Paris Fifth Ave., Inc. 219 F.3d 104, 108 (2d. Cir. 2000). See recently, Beebe and Sunder (2015), p. 49; See Kapferer (supra note 81).

108 Chiari (2009), pp. 5-7.

109 Davis (1992), pp. 17-18.
} 
defined as brand literate, fashionable consumers who make luxury choices based on their understanding of their own style. ${ }^{110}$ The current luxury consumer is smart, powerful, individualistic, demanding and above all can easily navigate between luxury and high street fashion to create their "distinctive" style. Luxury fashion brand owners are more than ever aware of this change and are now targeting their products to middle-class consumers. ${ }^{111}$ Companies are expanding either vertically ${ }^{112}$ or horizontally ${ }^{113}$ to target new consumers with the purpose of democratizing luxury. Armani, for example, has stretched its brand into new market segments through offering Armani products at lower prices (Armani Exchange) to make its products more affordable. Major fashion houses are collaborating with lower-end brands to make their products more accessible (see the H\&M and Balmain collaboration). ${ }^{114}$

This discussion sheds light on an often underemphasized finding. Consumption within the luxury fashion industry is now less about exclusivity and more about personalization and masstige. ${ }^{115}$ Thus, even if we equate dilutive harm with loss of exclusivity in its general sense, the significance of protection against blurring to preserve exclusivity has arguably lost rigor in recent years. ${ }^{116}$

In conclusion, the analysis shows that blurring is predicated on a complex, incompletely theorized and uncertain concept - trademark distinctiveness - which leaves the whole doctrine feeble. The uncertainty surrounding blurring stems from the fact that it cannot be measured quantitatively or proven economically and is becoming less important with the advent of the post-modern consumer society. ${ }^{117}$ Thus, continuing to rely on blurring as a separate cause of action to protect the modern functions will inject inconsistencies into a provision that is already riddled with its own contradictions. ${ }^{118}$ Having ambiguous standards for treating dilution will have chilling effects on trademark law. ${ }^{119}$ Whether tarnishment provides a more convincing argument is the focus of the next section.

\footnotetext{
110 Okonkwo (supra note 85), p. 297; Kapferer (supra note 81), p. 52.

111 Bellaiche et al. (2010).

112 Vertical brand extension involves introducing a brand extension in the same product category as the core brand, but at a different price point and quality level. See Keller and Aaker (1992), p. 36.

113 Horizontal brand extension occurs when an existing brand name is applied to a new product either in a related product class or in a product category completely new to the firm. See Sheinin and Schmitt (1994), pp. 5, 6.

114 Leaper (2015).

115 Generally see Silverstein and Fiske (2008).

116 Also see results of empirical study conducted by Kruger (2014).

117 Franklyn (2003).

118 Prescott (supra note 96), p. 102.

119 Scassa (2012), p. 877, Duncan (2010), p. 219.
} 


\subsection{Tarnishment}

Another form of harm recognized under Art. 10(2)(c) is detriment to the repute of the mark, also known as tarnishment. ${ }^{120}$ Whilst there is no consensus on a definition for tarnishment, it could be described as "the damage to the first mark which occurs when the second mark itself, or the products to which it is associated, either intentionally, or unintentionally result in damage to the reputation of the first mark". ${ }^{121}$ Arguably, when a mark is used by a third party on goods which are unsavory, new negative associations attach to this mark. ${ }^{122}$ Once consumers are exposed to these associations, the amount they are willing to pay for the original mark decreases, as does the overall social welfare. ${ }^{123}$ Evidently, the main aspect of tarnishment is thus reputable harm. Whilst the previous definition is as a matter of language intelligibility, it requires considerable elaboration, particularly in relation to the type of harm it includes. Hence, a just evaluation of the normative rigor of tarnishment requires addressing two key points. First, the elements of reputation that tarnishment intends to protect. Second, whether the concept of reputational harm exists practically, and if it does, whether it can be quantified and transferred into the legal sphere. As an introduction, the subsequent section will provide an overview of EU case law dealing with tarnishment.

\subsubsection{Tarnishment in Europe}

The concept of tarnishment within the EU jurisdiction has evolved considerably. Since the early introduction of tarnishment, courts had to address a range of issues to clarify the scope of its applicability and its limits. Subsequent case law explained critical points in relation to the relevant type of harm and required evidence. Yet there remains uncertainty in analyzing this cause of action, ${ }^{124}$ first given the implausibility of the legal reasoning adopted by courts in some instances, and second given the inherent weakness of this cause of action.

Broadly, EU courts dealing with tarnishment have established that detriment to the repute of an earlier mark requires a negative mental association in the mind of the consumer between the junior and the senior mark. ${ }^{125}$ As illustrated in the landmark case of L'Oreal, "such detriment may arise when the goods or services offered by third party possess a characteristic or quality which is liable to have a negative impact on the image of the mark". ${ }^{126}$ Courts noted that in addition to a

\footnotetext{
${ }^{120}$ Often, blurring and tarnishment are addressed simultaneously. See UK case Intel Corp v. Sihra [2003] EWHC 17.

121 Griffiths (supra note 19), p. 351. Also see Beebe (2006), p. 1150.

122 Emerson (2011), p. 482.

123 Landes and Posner (2003), p. 487.

124 Champagne Louis Roederer v. Gracia [2017] EWHC 289 (Ch) describing case law on tarnishment as being underdeveloped.

125 Intel Corporation (supra note 29).

126 L'Oréal (supra note 10), para. 40.
} 
negative association, it has to be shown that such association would have a detrimental impact on the earlier mark. ${ }^{127}$

A primary dilemma addressed by EU courts concerns whether potential detriment to repute is limited to cases of dissonant, obscene goods or whether it can extend to cover incompatible and low or inferior quality uses. Case law in this area reflects that potential detriment can certainly cover goods of an incompatible nature. ${ }^{128}$ As for low-quality goods, courts in L'Oreal did not eliminate the possibility of raising a tarnishment claim based on inferior quality. ${ }^{129}$ However, subsequent case law casts doubt on the possibility of relying on inferior quality as a premise for tarnishment. ${ }^{130}$ Furthermore, the EUIPO submitted that inferior quality cannot be advanced as a ground for opposing registration. ${ }^{131}$ The EUIPO relied on the possibility of non-use and subjectivity as the reasons for rejecting this argument. While the paper argues for a judicious approach in analyzing tarnishment, it seems difficult to rationalize accepting tarnishment in cases of dissonant goods while rejecting it in cases of inferior quality goods.

A second aspect of the L'Oreal standard, which requires validation, concerns the connotation of the term "negative mental association". The apparent simplicity of this statement is arguably deceptive, and certainly dangerous, in particular in relation to what constitutes or stimulates negative mental association. This is clearly reflected in EU case law. For example, in the case of Karelia Tobacco Company Inc. ${ }^{132}$ courts found that the use of Kappa on tobacco-related products is likely to produce negative mental associations for an earlier mark which is reputed for sports clothing. Although the above reasoning warrants some credibility given the obvious contradiction between the image of a healthy life style and tobacco, the same could not be said about subsequent cases.

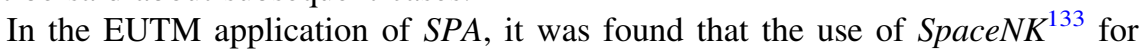
scouring and polishing preparation could be objected to by Owners of Spa, a company reputed for the production of mineral water. Courts reasoned that the pleasant connotations conveyed by mineral water do not mix seamlessly with detergents. Furthermore, "Mineral Water is not pleasantly associated by most consumers with incense or pot pourris". ${ }^{134}$ What is of extreme concern in this case is that inhomogeneous associations between the two marks were assumed to constitute negative mental association. More worryingly, the EUIPO, in its

\footnotetext{
127 EUIPO (supra note 16), part 3.4, pp. 47-61.

128 See L'Oréal (supra note 10).

129 R240/2004-2, WWRD Ireland IPCo LLC v. Assembled Investments Ltd [2010] unreported.

130 See Champagne Louis Roederer v. Gracia (supra note 124) describing case law on tarnishment as being underdeveloped.

131 EUIPO (supra note 16). Also see T-67/04 Spa Monopole, Compagnie Fermière de Spa SA/NV v. OHIM [2005] ECLI: EU: T: 2005, para. 49.

132 R 297/2011-5, Karelia Tobacco Company Inc. v. Basic Trademark SA (KAPPA) [2012] unreported, para. 38.

133 R-417/2008-1, Space NK v. SA Spa Monopole [2009] OHIM First Board of Appeal, para. 101.

134 Ibid., para. 10.
} 
decisions in the $L V$ case $^{135}$ and the El Corte Inglés case, ${ }^{136}$ ruled that the image of luxury and exclusivity conveyed by the earlier mark contradicts the content associated with the later mark. On this basis, the application for the registration of the later mark was rejected. While incompatibility can, in particular limited instances, stimulate a negative mental association, the approach of the courts reflects an inclination to assume any incompatibility as inevitably having such effect. This certainly stretches the boundaries of tarnishment considerably.

The final and perhaps most critical question addressed by the EU courts concerns the type of evidence that should be adduced as proof of tarnishment. In particular, will it suffice to show that the use of a junior mark would incite disgust or fear, or should it be proven that such feelings will impact consumers' perception? And if the answer to the latter is yes, what type of evidence should be provided? Generally, case law regarding evidence of tarnishment is significantly undeveloped. ${ }^{137}$ Without notable elaboration, courts state that the risk of detriment to the power of attraction of a mark is decided based on logical inferences, emphasizing that the alleged risk shall not be merely hypothetical. ${ }^{138}$

However, in making such logical inferences, courts tend to rely on the assertions made by the original trademark owners regarding their promotional efforts, advertising and their brand identity. ${ }^{139}$ For instance, in both Dulces and Azumi tarnishment was found based on the opponent's assertion that their trademark evoked a positive image since their products were healthy, tasty, authentic and of high quality, as reflected in their advertising strategy (printed media, television). Because animal foodstuffs and animal litter are incompatible with foodstuffs for humans, in both these cases it was concluded that these uses are likely to raise unpleasant associations. Hence, it was deduced that this will adversely affect consumers' perception of the earlier mark. ${ }^{140}$

It appears that once courts are satisfied that a use is likely to stimulate negative associations, detriment or possible detriment is easily accepted. Interestingly, AG Wahl proclaimed that like in the case of blurring, tarnishment requires evidence for change in economic behavior of the average consumer. ${ }^{141}$ However, apart from this case, change in economic behavior is limited to blurring cases.

\subsubsection{Evaluating Tarnishment}

Like blurring, tarnishment has been criticized on several grounds. Criticisms against tarnishment in many respects share the same logical grounds as those instigated

\footnotetext{
135 R 2124/2010-1 LN/ LV et al. [2011], paras. 28-30.

136 T-8/03 El Corte Inglés, SA v. Office for Harmonization in the Internal Market (Trade Marks and Designs Court) [2015] ECLI:EU:C:2015:807. A similar approach was used by the US Supreme case of Mosely v. Victoria Secret Catalogue 537 U.S.418 (2003).

137 E.g. T 624/13, The Tea Board v. OHIM [2015] EU:T:2015:743.

138 Ibid:; also see T61/16, Coca Cola v. EUIPO [2017] ECLI:EU:T:2017:877.

139 R-318/2016-5, Dulces v. Conservas HELIOS, S.A. v. Guangzhou Petshine Pet Products Co. [2016].

140 Ibid.; Azumi Ltd v. Zuma Choice Pet Products [2017] EWHC 45.

141 C-125/14 Iron v. Unilever [2015] ECLI:EU:C:2015:195. Advocate General Wahl.
} 
against blurring, particularly that language is not immutable, that consumers derive meanings from contexts and that the harm is not actual but rather speculative. ${ }^{142}$ In addition to the above, the competence of this cause of action as a normative foundation for modern trademark protection is undermined by several specific factors.

Primarily, it is often claimed that tarnishment intends to eradicate potential harm to the reputation of the famous mark. Questionably, in deconstructing the notion of reputation, it is being assumed that trademarks are always linked to a set of positive associations determined solely by trademark owners through developing their brand identity. Practically, however, trademarks are received, perceived and understood within the broader society. ${ }^{143}$ In many instances, meanings signaled by trademark owners through brands are transformed within the social nexus. ${ }^{144}$ For instance, by reference to $\mathrm{LV}$, one can argue that while trademark owners intended to build a reputation revolving around luxury, LV is also practically associated with pretension, overconsumption and consumerism. Hence, an effective assessment of reputation requires delving into the both the negative and positive reputational elements of a trademark. By acknowledging the existence of a potential negative reputational element, one can argue that protection against tarnishment - which encompasses the positive reputational elements exclusively - stifles freedom of expression, as it discourages any negative association with a trademark. This legitimate concern is of notable importance but has been addressed elsewhere. ${ }^{145}$ What should be emphasized here is that reference to reputational harm oversimplifies the concept of reputation. Rather, courts should transparently refer to the intention to protect "brand identity". 146

Another notable concern raised against tarnishment in general, and the CJEU interpretation in particular, concerns the rationality of distinguishing incompatible uses, dissonant uses and shoddy quality goods. Practically, if the possibility of a detrimental negative association is the basis for a tarnishment claim, there is no cogent reason to exclude shoddy quality goods from hypothetically spurring such negative association.

This brings us to the final and perhaps most compelling conundrum associated with tarnishment, in relation to the standard required for accepting a tarnishment claim. Specifically, whether it suffices that a junior use stimulates negative associations or whether proof that negative associations have been transferred to consumers should be provided. To elaborate, consider the very basic example of the Victoria Secret (VS) mark being used by a third party to promote sex-related products. Following such use, VS will generate two conflicting sets of associations. The first involves a classy, flirty, fashionable set of associations. The second involves a less respectable, arguably vulgar type of associations. ${ }^{147}$ Just as positive associations of the senior mark can transfer to the junior brand (transferability of

\footnotetext{
142 Rierson (supra note 31), p. 246. Also see Tran (supra note 31).

143 Elliot and Wattamasuwan (1998), p. 132. Also see Holt (1995), pp. 1-2.

144 Gangjee (2013), pp. 29-31.

145 Basma (2020), work in progress.

146 Handler (2016), p. 664.

147 Morrin and Jacoby (supra note 78), p. 1061.
} 
inherent goodwill), ${ }^{148}$ it is reasonable to accept that the contrary is true. ${ }^{149}$ Upon encountering VS, the negative associations created by the junior user will remain active, even if this happens unconsciously. ${ }^{150}$ The anti-ethical nature of such use is thus present in the sense that against the will of its owners, the mark VS may start signifying vulgarity. However, this is insufficient to conclude that the created negative associations are bound to have a quantifiable negative effect, such as decrease in purchase likelihood, purchase intention, etc. ${ }^{151}$

Recent cognitive studies in this area confirm the previous statement. An empirical study conducted by Bucaffoso et al. doubts the legitimacy of the negative feedback effects theory. ${ }^{152}$ A more recent study by Bedi and Reibesten sheds light on the difficulty of linking tarnishment to purchase likelihood. ${ }^{153}$ Even if one is to assume that this negative effect exists, the verification of the impact of tarnishment is almost unattainable. As in the case of the change in economic behavior requirement, any submitted evidence would be rather speculative, as it can hardly ever be proven to be exclusively associated with tarnishment. Thus, judgments will remain highly dependent on the economic prediction of courts about consumer tastes and their reactions to specific uses. ${ }^{154}$

Reasonably, thus, tarnishment as a cause of action should realistically protect consumer perceptions of the brand and should avoid the effect of the logical fallacy of requiring evidence of harm. From this perspective, tarnishment should be interpreted from a moral perspective, independent of sales and purchases. ${ }^{155}$ Since conclusive evidence of tarnishment is inaccessible, tarnishment need not be treated as a separate cause of action. Rather, tarnishing uses should be regarded as a compelling indication of the existence of a misappropriation claim. This point will be further addressed in the next section. ${ }^{156}$

\section{Unfair Advantage}

\subsection{Background}

Alongside blurring and tarnishment, the EU has resorted to misappropriation or free-riding considerations ${ }^{157}$ as a ground for extending trademark protection. Most

\footnotetext{
148 Basma (2016), pp. 71-78.

149 US case of Ty Inc v. Perryman (supra note 72), p. 511. Also see Tushnet (supra note 66), p. 523.

150 Ibid:; also see Bedi and Reibstein (2020), p. 702.

151 Bradford (2008), p. 1285.

152 Buccafusco et al. (2017), p. 341. Also see the discussion in Handler (supra note 146), p. 686. Also see Skyscape Cloud (supra note 52), arguing that any initial beliefs will be eventually dispelled.

153 Bedi and Reibstein (supra note 150).

154 See Victoria Secret (supra note 136).

155 See part 3.3.

156 See part 4.5.

157 A free-rider is defined as "one who obtains economic benefit at another's expense without contributing to it”. Black's Law Dictionary (2009), p. 737.
} 
obviously, prevention of misappropriation (free-riding) has been injected into the language of Art. 10(2)(c) of the TMD, which openly refers to "unfair advantage" as a third rationale for modern trademark protection. ${ }^{158}$

As a gateway to an analysis on unfair advantage, it is useful to refer to the CJEU ruling in the case of L'Oréal, in which it was concluded that a defendant should not be allowed to ride on the coattails of a famous mark. What lies at the core of unfair advantage is that a vendor who uses another's trademark should not be legally permitted to unfairly profit from this use. Driven by unjust enrichment considerations, this cause of action aims to prevent the misappropriation of someone else's reputation, effort or time without their consent. ${ }^{159}$ Under this reasoning, emphasis is placed on the moral unfairness of such use as opposed to the actual economic harm that may result from the use of a senior mark in unrelated markets. ${ }^{160}$

This approach, although profoundly criticized, for example for being unconfined, ${ }^{161}$ finds support in a blend of different rationales. According to Barnes, the Lockean theory of labor, the concept of unjust enrichment and the role of courts of equity in the society all provide support for this rationale. ${ }^{162}$ Justifying trademark protection based on the free-riding rationale can also be supported by economic arguments which will be advanced in the final part of this paper. Put simply, in light of the modern trademark functions, a free-riding approach to extending trademark rights appears to shift the emphasis from consumer deception towards a more "realistic appraisal" of all the interests worth protection. ${ }^{163}$ Before delving into the particularities of free-riding and the reasons under which it should be protected, the EU stance as reflected in case law will be considered.

\subsection{Unfair Advantage in Europe}

The earliest European judgment addressing unfair advantage is Premier Brands. ${ }^{164}$ Citing the German case of Dimple ${ }^{165}$ Neuberger J. noted that:

Courts have repeatedly held that it constitutes an act of unfair competition to associate the quality of one's goods or services with that of prestigious competitive products for the purpose of exploiting the good reputation of a competitor's goods or services in order to enhance one's promotional efforts.

\footnotetext{
158 As evident in the wording of Art. 10(2)(c) of the TMD of 2015.

159 Griffiths (supra note 19), p. 356.

160 Free-riding arguments have been brought to light in a variety of modern trademark contexts, including merchandising, parody, keyword advertising and comparative advertising cases.

161 Numerous scholars have written about the dangers of such a property-based view of trademark law. For example, Dogan (supra note 74), p. 103.

162 Barnes (2010), p. 470. Also see Jacob LJ, Court of Appeal (Civil Division), L'Oréal v. Bellure [2010] EWCA Civ 535.

163 Caleshu (1964), p. 741.

164 Premier Brands (supra note 22), para. 1092.

165 The Dimple Case [1985] GRUR 550.
} 
According to subsequent CJEU judgments, to determine whether an unfair advantage was taken, a global appreciation test must be applied. This test takes into account all factors relevant to the circumstances of the case, including the strength of the earlier mark's reputation, the degree of distinctiveness of the mark, the degree of similarity between the marks at issue, evidence of association between the two marks, the nature and degree of proximity of the goods or services concerned and the likelihood of dilution to the earlier mark. ${ }^{166}$ Interestingly, however, in practice, two particular factors have been decisive in ruling unfair advantage cases.

The first factor relates to whether the products are presented as imitations or merely as alternatives. Only in the former cases would the advantage taken be considered unfair. ${ }^{167}$ Problematically, the imitation factor suffers from serious theoretical and practical problems. ${ }^{168}$ For the purpose of this analysis it should be emphasized that by considering imitation as an element of unfair advantage, courts are not prohibiting the act of imitation itself, but rather the use of an established mark to draw attention to the imitated product. Accordingly, it is illogical to apply general imitation arguments to the specific context of trademark law. Moreover, relying on this element to determine liability is unpractical, as drawing a line between imitations and alternatives is challenging. Existing case law implicitly reflects a view in which products offered within a similar price range are assumed to be alternatives. If this inclination is true, it should certainly be reconsidered. To avoid the practical problems of attempting to draw such a distinction, it is proposed that regardless of whether the goods offered are imitations or alternatives, courts should focus on the substantiality of the advantage derived, a point which will be substantiated below.

The second decisive factor often advanced in this context is the intention of the competitor/third party. In Specsavers, it was ruled that Asda clearly and intentionally gained an advantage by drawing on the reputation of an already established mark. In essence, "because Asda attempted to benefit from the power of attraction, the reputation and the prestige of Specsavers and to exploit, without paying any financial compensation, and without making efforts of his own, the marketing effort expended by the proprietor of the mark then this advantage was regarded as unfair". ${ }^{169}$ This factor was also raised in the UK case of Jack Wills, ${ }^{170}$ in which it was claimed that, among other things, the defendant (House of Fraser) reproduced the pigeon logo, which intentionally represents Jack Wills. ${ }^{171}$ While intention could be considered in the analysis, the emphasis on intention solely

\footnotetext{
166 L'Oréal (supra note 10). Also see C-85/16 Tsujimoto v. European Intellectual Property Office [2018] ECLI:EU:C:2018:349.

167 Ibid., L'Oréal, para. 82, Interflora v. Marks and Spencer (supra note 10), C-229/03 Gillette Co v. L-A Laboratories Oy [2005] ECLI:EU:C:2005:177, para. 35.

168 See US case Smith v. Chanel, 402 F.2d 526 (9th Cir. 1968). Arguments suggesting that the prohibition of imitation is anti-competitive have arisen. Proponents of this view suggest that imitation is the "lifeblood of competition" and should be embraced.

169 Specsavers International Healthcare Ltd. v. Asda (supra note 103). Also see Red Bull GmbH v. Sun Mark Ltd and Sea Air \& Land Forwarding Ltd [2012] EWHC 1929 (Ch), para. 103.

170 Jack Wills Ltd v. House of Fraser (Stores) Ltd [2014] EWHC 110 (Ch).

171 See Mars. Inc [2014] Commercial Court of Brussels (Chamber E).
} 
(particularly if divorced from other case-specific factors) could stretch the boundaries of unfair advantage. ${ }^{172}$

An interesting application of unfair advantage can be seen in light of the UK Court of Appeal decision in the case of Whirlpool. ${ }^{173}$ Here, in evaluating the nature of the advantage taken by Whirlpool, courts considered the fact that the junior user had a strong goodwill separate from that of the senior trademark owner, thus concluding that the registration of a shape mark similar to that of the original trademark did not constitute an unfair advantage. Courts here did not limit the analysis to the fact that the user derived a commercial benefit from such use, or had the intention to do so. ${ }^{174}$ This judgment reflects the capability of the judiciary to employ a functional analysis in evaluating the nature of the advantage taken by the third party, beyond the spectrum of the imitation and intention.

The previous interpretation of EU case law with respect to free-riding engenders two main questions: firstly, why should the free-riding rationale endure despite the intense criticisms against its normative rigor? And secondly, what is the most favorable approach to interpret this rationale in practice, taking into account dilution-based considerations? Thus, the subsequent section will discuss this rationale, its underpinnings, its validity and its rigor using examples from the luxury fashion industry as demonstrative tools. The section will explain why the free-riding rationale can be rationalized as the main basis for extended trademark protection, though within clear and limited parameters. This view certainly runs contrary to Jacob LJ's assertion that unfair advantage should only constitute a claim in the presence of dilution.

\subsection{The Reality of Free-Riding}

Within academic literature, there has been disagreement as to whether the use of a mark in a non-deceptive manner could actually generate an advantage for junior users, especially if a mark is used on unrelated goods or in unrelated markets. Lemley and McKenna argue that using similar marks on unrelated goods and services cannot have any practical effect unless consumers are confused as to the source, thus dismissing free-riding as a logical ground for extended trademark protection. ${ }^{175}$ Their view is based on the assumption that if in cases of likelihood of association junior users only benefit in restricted conditions, then naturally in the absence of such likelihood a junior user cannot benefit. Thus, there is no case for free-riding. Anyhow, Lemley and McKenna argue that even if free-riding exists, it is only for a short period of time. ${ }^{176}$ If these claims are correct, then attempting to argue for a free-riding rationale for extending trademark protection is purposeless.

\footnotetext{
172 See part 4.5 .

173 Whirlpool Corp v. Kenwood Ltd [2009] EWCA Civ 353.

174 Ibid.

175 Lemley and McKenna (2012), pp. 160-161. Also see McKenna (2009), p. 63.

176 Gervais et al. (2013), p. 131.
} 
However, the main shortcoming within the previous claim is that it overlooks the significance of brand love in purchase decisions. ${ }^{177}$ While consumers are becoming increasingly sophisticated and aware of the links between brands, ${ }^{178}$ they are simultaneously developing affective, interpersonal feelings towards brands. ${ }^{179}$ As a result, consumers become obsessed with owning anything bearing the logo of their preferred brand. This view can be illustrated by reference to several trends from within the fashion industry.

Consider the example of a cake design company offering customers, at premium prices, cakes featuring designs and logos of famous marks. In this case consumers are fully aware that there is no connection between the brand and the cake manufacturing company, yet they choose to purchase them at such a price, principally because of the communicative value the logo featured on the cake offers them (both internal and external communication). Here, the trademark is used by the third party in an unrelated market, yet it may prompt consumers to purchase goods to satisfy a certain hedonic need. This example presents a clear case of free-riding which arguably "unjustly" enriches the junior user. ${ }^{180}$

A second scenario to point out is that in which a trademark is used in a nonconfusing way, yet in a way that brings to the attention of consumers a range of imitated (or alternative) products. In the aforementioned case of L'Oréal, for example, it is not difficult to argue that the use of the L'Oréal mark to bring to the attention of customers a range of perfumes with an identical smell will advantage the junior user. Also, in cases of referential use, it is not difficult to see how a (hypothetical) third party purchasing the LV keyword to advertise his own goods would advantage the junior user, who benefits from being able to draw attention to his own products. The fashion industry in particular is an industry in which junior users (especially those operating in low-end markets) strive to draw attention to their products by emphasizing their similarity to high-end products. ${ }^{181}$

Free-riding, thus, can obviously exist. However, the question which emerges is whether such acts of free-riding should be legally prohibited, and if so on what normative premise. Thus, it is crucial to explore the various normative theories on which free-riding considerations can be explained. As the analysis will reveal, neither a deontological approach nor a purely economic approach per se can explain the extension of trademark protection based on free-riding considerations. However, economic considerations can be used as supporting evidence for protection against

\footnotetext{
177 For a discussion on brand love see Caroll and Ahuvia (2006).

178 This development in consumer behavior can be relied upon to argue for stricter criteria in determining confusion. This remains beyond the scope of this thesis.

179 Basma (2016), p. 220. Also see Caroll and Ahuvia (supra note 177), p. 171.

180 Corresponding to the court decision in the cases of Odol, Landgericht Elberferd [1925] NJW 502, The Dimple Case (supra note 165). Ng-Loy (2012). The French Civil Code also includes a similar principle, "concurrence parasitaire", which prevents another trader from using another's trademark or packaging in the absence of confusion.

181 Forever 21, Zara, etc. all operate primarily through intentionally replicating high-end fashion designs.
} 
free-riding. This combined approach will help exclude the risk that could result from blanket prohibition against free-riding. ${ }^{182}$

\subsection{Deontological Approaches to Extending Trademark Protection}

\subsubsection{Lockean Theory of Labor}

The Lockean labor theory, ${ }^{183}$ being the most common articulation of free-riding, is a good starting point to this section. ${ }^{184}$ According to this theory, subject to the Lockean Proviso, labor which has been applied to an object with no owner becomes owned by the subject. ${ }^{185}$ "Furthermore, one man may not reap where another has sown, nor gather where another has strewn". ${ }^{186}$ Simply put, an individual who exerts labor upon an object and transforms it into something useful and worthy of protection should be the only person reaping the benefits of this labor, and the contrary is true. ${ }^{187}$

In the context of trademark law, a brand owner is the laborer who by mixing his efforts with raw material creates a valuable brand. Since a trademark proprietor creates brand meanings, then only trademark owners have a proprietary right to exclude others from using this mark. ${ }^{188}$ This argument is in line with the reward rationale that drives protection for most intellectual property law. ${ }^{189}$ Applying the Lockean theory of labor to trademark law is contentious for several reasons. ${ }^{190}$

First, this theory in its initial formulation was intended for tangible property. ${ }^{191}$ The main problem here is that treating intangible property as property in the legal sense may generate problems. ${ }^{192}$ Second, it should be recalled that the theory is restricted by the "no harm principle", which purports that if the appropriation of an un-owned object worsens the situation of others then such ownership needs to be

\footnotetext{
182 This view is supported by Lemley and McKenna (supra note 175). It is worth noting that contrary to civil law countries, common law regimes including the UK give precedence to competition considerations over fairness, considering fairness to be actionable only in very extreme cases. See LaFrance (2011). Also see Huntley and Stephen (1995).

183 For a detailed analysis on the theory see Locke (1964).

184 On the contrary, Kenneally argues that the Lockean theory of natural property should not per se be relied upon. See Kenneally (2015), pp. 289, 301.

185 Locke (1993), p. 274.

186 US cases of International News Service v. Associated Press, 249 U.S. 215 (1918) International News [1918] p. 238 ; J. I. Case Plow Works v. J. I. Case Threshing Machine Co. [1916] 162 Wis. 185, 201, 155 N. W. 128.

187 Gordon (1992), pp. 166-175. Also see Locke (supra note 185).

188 Isaac (2000), p. 273.

189 Gordon (supra note 187). For a fuller account of this theory see Spence (1996).

190 Naser argues that although this theory is the most suitable to justify copyright and patent protection, it is not applicable in the context of trademarks. See Naser (2007), p. 6.

191 Also see Spector (1989). For a detailed analysis on the problems of applying the Lockean theory in the context of trademark law, see Kenneally (2014).

192 Moskin (1993), p. 83 TMR 122. In contrast, see Carter (1992), pp. 720-723.
} 
prohibited. ${ }^{193}$ In the case of trademarks, it is arguable that granting monopolistic property rights over a word will affect the common pool of marks and will not leave enough goods to be used by others, rendering absolute protection of trademarks harmful. ${ }^{194}$ Third, unlike literary and artistic work, trademarks never fall in the public domain. Therefore, continuing to grant rewards for trademark owners based on the Lockean theory of labor justification results in infinite monopolization of the communicative value of the marks, a privilege which is disproportionate to the effort expended in creating brand meanings. ${ }^{195}$

Finally, consumers contribute significantly to the creation of brand meanings and the communicative value which largely drives extended trademark protection. Thus, for the reward argument to be valid, the law should strive to reward not only trademark owners, but equally consumers who participate in the creation of brand meanings. ${ }^{196}$ The profits associated with sowing thus are not all legitimately the right of the agent. So, while the labor theory may succeed in regulating the producer-producer relationship, it overlooks the producer-consumer relationship, which especially now needs to be incorporated in establishing the limits of trademark protection. ${ }^{197}$ As a response to this claim, it has been suggested that consumer rights can be realized by allowing the public to invoke and change brand meanings as part of the social discourse. ${ }^{198}$ While this suggestion entails some credibility, given the other criticisms against this rationale, it can be concluded that the moral case for accepting the natural rights of corporations in the monopolization of brand meanings remains weak. ${ }^{199}$

\subsubsection{Unjust Enrichment and Moral Permissibility}

The main difference between Lockean arguments and the unjust enrichment theory is that the former focuses on the right of the plaintiff to capture the full benefit of his investment, while the latter is concerned with the defendant and the unfairness that emerges from him acquiring an undeserved benefit. ${ }^{200}$ Unjust enrichment is a flexible doctrine, based on principles of justice and equity, empowering courts to recognize equitable causes of action in certain circumstances. ${ }^{201}$ The doctrine of unjust enrichment supports an independent cause of action that aims at the

\footnotetext{
193 Nozick (1974), p. 175.

194 Waldron (1988), p. 210.

195 Isaac (supra note 188), p. 273.

196 Basma (supra note 15), pp. 84-88 arguing that consumers receive messages through trademarks and decode them against their own background. So, although brand owners invest in the creation of "brand meanings", consumers also play a significant role either through circulating solid information which the brand signals, or through re-interpreting brand meanings that trademark owners attempt to infuse into their brands.

197 Sheff (2013), pp. 761, 773

198 Gordon (1993), pp. 1556-1559.

199 Sheff (supra note 197), p. 815.

200 Onassis (1984), p. 261.

201 Restatement (Third) of Restitution and Unjust Enrichment, 1cmt. B (2011).
} 
disgorgement of unjust gains since these are contrary to good morals. ${ }^{202}$ Unjust enrichment purports that benefit obtained from others in certain cases necessitates that the beneficiary makes restitution or re-compensates them. ${ }^{203}$

Given the communicative strength of trademarks, ${ }^{204}$ it is not difficult to understand how an entity that uses another entity's distinctive trademark may earn unjustified benefits. ${ }^{205}$ The implications of this are manifold. On one hand, the freerider will curtail the costs associated with marketing and branding a new product, which have now proved to be extremely expensive. ${ }^{206}$ Simultaneously, he can minimize the risk of failure which he may face in entering new markets. This is not only unfair for trademark owners whose marks are being unjustly exploited, but also for new entrants who prefer to exert genuine effort in branding and marketing their products. These may be compelled to sacrifice either the quality of their products or promotional budget to be able to compete effectively in the market. ${ }^{207}$ Bottom line, the free-rider will be able to sell his products at lower prices since he is not paying the full costs of production, whilst the competitor will have to incur extra costs. ${ }^{208}$

At first glance, unjust enrichment appears to provide the ideal basis for remedying the wrong at issue, thus justifying extended trademark protection. Once it is acknowledged that the second user is unjustly enriched by the use of the senior trademark, it seems perplexing as to why this rationale (as a general theory) is subject to this much criticism. Indeed, the intuition of fairness cannot be utterly disregarded, especially when entire businesses are built on the aggregation of reputation of well-known marks. ${ }^{209}$ This view is supported by Rawls' observation on the morality of free-riding, which reasons that "a person who has accepted the benefits of the scheme is bound by the duty of fair play to do his part and not to take advantage of the free benefit". ${ }^{210}$ Viewed from this perspective, prevention of unjust enrichment provides a solid premise on which the modern functions can be protected, even if evaluated in light of the criticisms instigated against it.

A plethora of jurists argue that this rationale is too idealistic, especially if placed within the nexus of a society which dedicates itself to promoting economic salvation and the need to protect the public interest. Objectors to unjust enrichment stipulate

\footnotetext{
202 Ibid. Coleman (1992), p. 284.

203 Black's Legal Dictionary (2004).

204 Basma (supra note 15), pp. 144-158 for a discussion on the communicative function of trademarks.

205 This benefit was confirmed in a number of empirical studies; Keller and Aaker (1992); Barnes (supra note 162).

206 Dinwoodie and Janis argue that limiting trademark functions to source identifying functions undermines the multi-billion-dollar industry of brand merchandising and product design. See Dinwondie and Janis (2007), p. 1654.

207 Since the free-rider avoids the costs of making the source indicator a familiar reference for consumers, he can increase his spending on the actual products, thus improving their performance, their features and their quality.

208 US case of Dresser-Rand v. Virtual Automation, Cp. 361 F.3d at 839 (2004).

209 Kenneally (supra note 184), pp. 294-301. Also see US Int'l News Serv. v. Associated Press, 248 U.S. 215 (1918).

210 Rawls (1964), p. 10. Hart also argued that "we are morally obligated to obey the law because freeriding is unfair”. See Hart (1955), pp. 185-186.
} 
that morality and economic efficiency are not always congruent, and in fact are usually contradictory. Converging these two concepts is believed to be challenging, and there is a general tendency to protect the former at the expense of the latter. ${ }^{211}$ Lemley, for instance, advances that in a market economy, the only relevant aspect which dictates legal interference is whether producers are generating enough return to cover their costs, including making a reasonable profit. The fact that the consumers value the good for more than the price or that others also benefit from the products should not be considered legally problematic in his view. ${ }^{212}$ This view on the economics of free-riding is limited and thus objectionable, as will be elaborated subsequently. ${ }^{213}$

Unjust enrichment-based arguments are also criticized on the premise that one cannot grant people benefits and then demand payment in return. ${ }^{214}$ The essence of this argument is that the presumption that free-riding is immoral is inherently erroneous. Based on Hume's no-ought-from-an-is suggestion, ${ }^{215}$ it is argued that one should not deduce that free-riding is immoral merely because they believe it ought to be immoral. ${ }^{216}$ Adopting Nozick's notion of morality, one would be able to argue that impermissible free-riding ought to be legally permissible even when such free-riding does not serve the public interest. ${ }^{217}$ This argument goes too far and is neither commended nor acceptable. Instead of arguing that all free-riding should be permissible, one can attempt to draw a line between permissible and impermissible and develop a principle of law accordingly.

The privileges following from the recognition of fuller property rights in trademarks is another argument raised against unjust enrichment. Unjust enrichment, once applied to the trademark context, implies that trademark owners have thereby created a thing of value through advertising and branding: a thing of value is property. The creator of property is entitled to protection, and the third party should not benefit from the value of this property. ${ }^{218}$ It is suggested that treating a trademark, which is in essence language of the commons, as property will result in the grant of "inequality in the commercial exploitation of language" in favor of trademark owners. ${ }^{219}$ This argument involves a level of reliability. However, whilst trademarks are not property in the literal sense, trademarks entail specific property

\footnotetext{
211 Ibid., Dorsen (1985), p. 923. Dorsen labeled dilution as a satiric misappropriation which, although it may hurt feelings, should not be actionable, as the defendant has not committed a wrong.

212 Lemley (2005), p. 1050.

213 See part 4.5.1.

214 Nozick (supra note 193), p. 95.

215 Based on the idea that you cannot make moral conclusions from non-moral premises. For a detailed analysis see Hume (1896).

216 Kenneally (supra note 184), p. 308. Nozick's claim that free-riding cannot ground an enforceable duty to obey the law has been met with objections from a number of philosophers who formulated new versions of free-riding principles. For example, see Arneson (1982), Klosko (1987), pp. 245-253.

217 Gordon (supra note 187), p. 181.

218 Pattishall (supra note 104), p. 620, citing Mishawaka Rubber (1942) Sec. 205.

219 Cohen (1935), p. 816.
} 
elements and thus bear protection based on quasi-property interests. ${ }^{220}$ Recognizing property rights in trademarks is necessary for the protection of trader interests in the exclusive use of a source designator and for building up their goodwill, ${ }^{221}$ which constitutes the core of the recognition of trademark rights.

Based on the above, it can be concluded that an argument which envisages freeriding conferring benefit on its recipient as never being morally wrong is questionable. This is particularly true in cases in which the intention of the party to profiteer from the senior mark is incontestable. By reference to the example of companies selling mugs bearing famous logos, there is no convincing explanation as to why a junior user would sell Chanel mugs except to exploit the affection consumers have developed towards the original brand. So there is no justification as to why the law should tolerate this form of profiteering. Whilst in other fields of intellectual property, a certain level of free-riding can further innovation or technical advancement, the same cannot be argued in the context of trademarks. ${ }^{222}$ On the contrary, entirely dismissing free-riding as a ground for protection actually encourages third parties to rely on established trademarks to sell products, which may sometimes discourage creative work, especially in industries which rely heavily on the aesthetics of products.

Also, researchers forcefully attacking trademark owners for manipulating consumer demand ${ }^{223}$ - an argument which the author does not entirely agree with $^{224}$ - overlooks the fact that by permitting third parties to exploit the affective emotions consumers develop towards brands, they are contributing to strengthening the emotional appeal of brands in the marketplace. Furthermore, given the increased emphasis on corporate social responsibility within the legal landscape it should be accepted that entities should be encouraged to behave ethically not only towards consumers, employees and the environment but also towards competitors (direct or indirect). Finally, whilst it is true that many competitive acts may be damaging to a competitor and remain legally tolerable, these acts remain within the boundaries of genuine competition. It is difficult to see how free-riding, in instances where it is intentional and explicit, can be regarded as a genuine form of competition.

Taken together, despite the abundant criticisms cited against unjust enrichment as the basis for the free-riding rationale, it still constitutes the most convincing ground for encompassing the new commercial realities and thus for extending trademark protection. The immorality inherent in free-riding in specific instances certainly constitutes more justifiable grounds than the conceived fantasy of alleged economic harm resulting from dilution. Also, whilst an unregulated view on free-riding could

\footnotetext{
220 McCabe (2000), p. 1835.

221 Chronopoulos (2014), p. 255.

222 Franklyn (supra note 117).

223 For example, see Brown (supra note 1); Timber (1949).

224 Basma (supra note 15), p. 232.
} 
be harmful, a limited, well-articulated free-riding cause of action is not only unharmful to the public interest but also advantageous in certain circumstances. ${ }^{225}$

\subsection{Limiting Free-Riding}

Although challenging, ${ }^{226}$ it is crucial to develop well-defined boundaries which recognize instances in which the benefit acquired by third parties merits legal intervention. To achieve this objective, this paper proposes a two-step test. The first step derives from Kenneally's proposition that limiting free-riding should start with an expectations-based approach for determining the morality of free-riding. Interpreted from this perspective, the permissibility or prohibition of free-riding initially depends on the motivation of the free-rider, or in other words, the extent to which the free-rider can say that he has accepted a benefit only because it was available for free. Contrarily, if it can be shown that a free-rider obtained a benefit he had a decisive reason to seek at his own expense, then he bears an obligation to contribute something if asked by the party whose investment created the free-riding opportunity. $^{227}$

Interpreted through the prism of trademark law, this reasoning purports that the free-rider who uses an existing mark principally to promote his business, for example, cannot claim that he accepted a benefit solely because it was freely available to him, as he has enough reason to seek such benefits at his expense. ${ }^{228}$ Hence, he should be expected to contribute something to trademark owners. Despite the theoretical credibility of the moral expectation argument, it remains too broad, thus potentially granting trademark owners overextended rights. Accordingly, it is proposed that intention, as explained by Kenneally, is important so far as it justifies why a mark owner can expect compensation. Hence, a complementary second step which interprets intention in light of other factors, particularly economic ones, should be employed. ${ }^{229}$ Although considerations that may be relevant in determining the impermissibility of free-riding cannot be exhaustively listed, general guidance is useful.

\subsubsection{An Economic Approach to Free-riding}

In analyzing modern trademark protection, several attempts have been made to transplant the efficiency-based arguments manifested by the need to prevent market failure resulting from informational asymmetry ${ }^{230}$ into modern trademark

\footnotetext{
225 Callmann notes that as long as it is borne in mind that these rules cannot be the same as those which govern relations between men at peace with each other, there is nothing in the competitive relationship which makes it incapable of being governed by law. Callmann (1942), p. 601.

226 Swann and David (1994), pp. 252-253.

227 Kenneally (supra note 184), p. 310. Also see Klosko (supra note 216).

228 Kenneally (supra note 184), p. 309.

229 Part 4.5.1.

230 For example, see Kratzke (1991), arguing that the informational and identification role of trademarks is the source of their value and the basis of trademark protection.
} 
law. $^{231}$ The end result was a series of speculative, unconvincing economic arguments. ${ }^{232}$ Hence, this section looks beyond the classical view of economics to discuss how an economic reasoning can act as an ancillary to the moral reasoning provided above, as the second step for determining the permissibility of freeriding. ${ }^{233}$ Arguably, this hybrid approach (moral and economic) will help confine the misappropriation rationale. Prior to delving into the specific economic factors, it is useful to discuss whether an economic case for free-riding could be advanced at all.

From an economic standpoint, extended trademark protection is commonly explained based on an incentive-based argument. ${ }^{234}$ This view provides that freeriding merits legal intervention because failing to intervene would discourage private investment. Thus, in order to maintain market efficiency, free-riding needs to be eliminated. ${ }^{235}$ However, Lemley rightfully objects to this view, arguing that trademark owners will continue to invest in brands because in order to compete effectively they need a strong brand. ${ }^{236}$ Indeed, the US anti-dilution experience shows that as long as trademark owners are capturing enough benefits, they will continue to invest even if they do not fully internalize positive externalities of their investments. $^{237}$

While Lemley's objection is strictly speaking understandable, it is flawed in the sense that it assumes that even competition which is predicated on non-constructive efforts should be embraced as long as it enhances the price value of commodities, thus equating economics to profit. However, the paper argues that a complete laissez-faire (unethical) competitive environment can be economically counterproductive. Particularly, when free-riding is permitted limitlessly, unhealthy competition will emerge. ${ }^{238}$ Although it is true that rivalry is an essential part of the order of struggle, this rivalry should be constrained by rules which ensure a procompetitive, fair process. ${ }^{239}$ These rules are crucial, as they ensure that each trader succeeds with his unaided efforts.

Generally, the prohibition of misappropriation based on fairness considerations has been objected to on two economic grounds. The first argument purports that all

\footnotetext{
$\overline{231}$ McKenna (2007), pp. 1850-1873.

232 Desai (2018), p. 612.

233 Griffiths argues that in extending trademark protection, an economic analysis taking into account the interests of various market interests should be implemented. See Griffiths (2008), p. 250. Generally, the search cost reduction and quality assurance theories cannot explain extending trademark protection based on a "goodwill protection". Quite the contrary, from the perspective of these theories, it is arguable that extending trademark protection based on extended goodwill may stifle competition. See Cadbury Schweppes Pty Ltd v. The Pub Squash [1981] A.L.J.R. 333, para. 339.

234 This view was emphasized in the US case of National Basketball Association v. Motorola Inc., 105 F.3d 841 (2d Cir. 1997) p. 853.

235 Ibid., p. 853.

236 Lemley (1999), p. 1705.

237 Lemley (supra note 212), p. 1057; Frischmann and Lemley (2007), p. 258.

238 Ricketson (1984), pp. 1-3.

239 Nims (1929) in Callmann (supra note 225), p. 596.
} 
economic arguments advanced in favor of the prohibition of free-riding - such as facilitation of competition in mature markets - are outweighed by public concerns. $^{240}$ In this respect one can counter-argue that in the context of trademark law, free-riding occurs when a defendant seeks to gain a competitive advantage for himself in his own area of activity by stealing an image which the plaintiff has developed in association to his products. In such a situation, there seems to be little, if any, public interest in allowing the continuance of this practice, as the prohibition of image stealing does not prevent a rival transfer from undertaking his own promotional campaign. ${ }^{241}$ The general condemnation that misappropriation-based protection creates trade barriers is largely speculative and requires functional caseto-case determination. In fact, as Chronopoulos points out, the impediment of market entry flowing from trademarks can in certain industries help keep the number of brands to optimal levels. ${ }^{242}$

Practically, one may take a step further and suggest that the public is better off with the prohibition of such practices. One supporting argument for the latter view lies within the "characteristic approach" to consumer behavior, which measures utility by the availability of product characteristics and not by the number of units produced. $^{243}$ Generally, consumers are often consciously seeking to satisfy a preference for specific product characteristics, and thus the protection of the inherent goodwill through preventing free-riding helps protect product variety to the benefit of consumers. ${ }^{244}$ Viewed from this perspective, an economic case for freeriding can be advanced.

As for the second economic objection to misappropriation, it is argued that identifying the damage suffered by the plaintiff is impossible, ${ }^{245}$ particularly in the absence of deception. ${ }^{246}$ Although the author disagrees with the view that harm should be a prerequisite to a free-riding claim (since unjust enrichment focuses on the benefit the claimant acquires), the existence of damage can certainly support such a claim. While economic harm cannot be objectively quantified, it cannot be entirely dismissed.

The first type of harm occurs when the plaintiff is deprived of the opportunity to internalize the benefits of creating a famous mark by expanding their operations into new markets. ${ }^{247}$ Brand expansion is indeed a crucial strategy for external growth. ${ }^{248}$ This harm is manifest in instances in which the free-rider operates in a similar market to that of the plaintiff and the goods he offers are a natural expansion of the

\footnotetext{
$\overline{240}$ Senftleben (2008), pp. 54, 55.

241 Terry (1988), p. 308; Ricketson (supra note 239), p. 26.

242 Chronopoulos (supra note 221), p. 274.

243 Ibid., p. 272. Carbal (2000), p. 208.

244 Basma (supra note 15), p. 192.

245 Lemley and McKenna (supra note 175), p. 170; Beebe (2014), p. 63.

246 Ibid.

247 Generally see Marks (1978), Morck (1992), pp. 41-56.

248 Keller (1999), pp. 102-112.
} 
plaintiff's goods. In such cases, the defendant's conduct can clearly demonstrate harm resulting from free-riding. ${ }^{249}$ The second type of harm emerges from the use of a mark on goods and services in a tarnishing manner. ${ }^{250}$ The unfavorable impression that might attach to the plaintiff's mark as a result of third-party use increases the likelihood of damage. Tarnishment and its implications have been discussed previously and it was concluded that while quantification of the economic harm is difficult, holistically, obvious cases of tarnishment can validate a misappropriation claim.

Having established that an economic case for free-riding can be advanced, this section aims to explore the second step, which can help limit the exclusionary effort purported by this rationale. Generally, ruling on trademark cases certainly requires a functional case-to-case analysis. However, the paper proposes that a general formula could be advanced to help analyze such cases. Simply put, free-riding in the context of trademark law should be prohibited if in addition to the intention factor it can be proven that the defendant has received a substantive advantage in the market in which he operates, or if the plaintiff has suffered a substantive disadvantage (or both).

Several factors could be advanced in evaluating the nature of the competitive advantage gained by the defendant. For example, if the use allows the junior user to avoid substantial costs associated with production in his own market or to increase the price of his commodities, then the advantage should be deemed unfair. Similarly, if the defendant's products are principally sold due to the use of the mark on the unrelated products, free-riding should not be legally permissible.

A similar argument can be proposed in evaluating the substantiality of the harm inflicted on trademark owners. For example, if the third party starts operating in a market which is consistent with the core values of the brand (adjacent brand categories), ${ }^{251}$ then such disadvantage should be regarded as substantial unless the defendant can prove otherwise. However, in markets in which the core value of the original brand is not in line with those of the defendant, an advantage is to be regarded as substantial only if evidence that the right-holder's intent to extend the use of their mark into this market is provided. Evidence of the existence of tarnishment or blurring can certainly be used to support a claim of substantive disadvantage of the senior mark holder. To exemplify this, two hypothetical cases from the fashion industry will be considered. The first example is that of the cake manufacturer who sells customized cakes bearing brand logos at exaggerated prices. The second case is that of a tourism company that operates under the name Oasis, although this trademark is already in use by a leading fashion brand.

\footnotetext{
249 For a criticism on this view see Lemley and McKenna (2012), p. 2117.

250 Ricketson (supra note 239).

251 Brand Adjacency is defined as the "extent to which a particular brand extension is consistent with the values embodied by the core brand". For example, LV producing perfumes, clothing and accessories is considered adjacent; however, if the company starts producing toothpaste, it is considered non-adjacent brand extension. Aaker (supra note 62). Also see Reddy et al. (supra note 85).
} 
In the first case, the goodwill of Chanel clearly generates demand for the cake manufacturer (particularly given the strength of the emotional connection consumers develop with brands in this industry). ${ }^{252}$ More concerning is the fact that such use allows the junior user to discriminate in prices in the market in which he/she operates. To avoid this, competitors within the industry may follow the approach adopted by the junior user. Arguably, this will curtail creativity in an industry which should be driven by such creativity. On balance, taking into account the particulars of the products advertised, the message delivered and the buyers in question, such use ought to be prohibited. On the contrary, in the second case, although the tourism operator may have benefited from the familiarity of the Oasis fashion brand, this advantage in unlikely to confer an overall substantive advantage on the third-party user. The fact that this brand has a suggestive meaning within the market in which it operates can constitute supporting evidence for this finding. ${ }^{253}$ If, for example, a case emerged in the pharmaceutical industry, a more stringent approach should be adopted, as it is accepted that branding activities in this industry aim to suppress competition from generics. ${ }^{254}$

Applying this reasoning to the previously decided case of L'Oréal, the advantage gained by Bellure can only be regarded as unfair if evidence can be presented that Bellure's goods are sold primarily because of the importation of the L'Oréal reference. ${ }^{255}$ Courts shall evaluate this by reference to all relevant economic factors, such as the fact that that the defendant has a separate goodwill or that the use is likely to affect the power of attraction of the mark. As correctly decided in the case of Whirlpool, courts should consider intention but look beyond it to evaluate the nature of the advantage taken. The potential impact of a trademark use on the behavior of the defendant's customers is a crucial factor for determining whether an advantage was unfair. Although this requirement contains a level of ambiguity, ${ }^{256}$ it serves well in evaluating the substantiality of the advantage taken. ${ }^{257}$ By explicitly noting that intention to exploit a brand image is not per se sufficient to establish liability, courts will be placing reasonable limits on the misappropriation rationale. $^{258}$ In general, the analysis should be tailored; it should not treat trademark use as a homogeneous activity independent of specific market factors. ${ }^{259}$

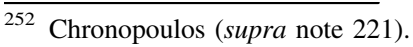

253 US case of United Lace (1915).

254 Lemley and McKenna (supra note 249); Harris (1964), p. 90.

255 See L'Oréal (supra note 10).

256 Such determination requires evidence mainly obtained through consumer surveys. Despite the increased use of surveys in some jurisdictions (US), their credibility has been contested. E.g., Manta (2007), pp. 1046-1056

257 SILGA AG [2007].

258 Also see Environmental Manufacturing (supra note 85), para. 52 stating that "Such a finding may be established, in particular, on the basis of logical deductions made from an analysis of the probabilities and by taking account of the normal practice in the relevant commercial sector as well as all the other circumstances of the case".

259 Lemley and McKenna (supra note 254), p. 2117. Leffer (1981), p. 46.
} 


\section{Conclusion and Findings}

Using the luxury fashion industry as an evaluative tool, the analysis revealed that the dilutive harm theory is very vague and ill-defined and, despite its allure, cannot justify the recognition of the modern functions and their extended protection. This finding is reinforced by the fact that the CJEU, in interpreting Art. 10(2)(c), has failed to employ a consistent analysis in interpreting dilutive harm, possibly because the tests employed for this purpose were highly subjective.

The much-criticized misappropriation theory, on the other hand, despite lacking obvious economic rigor, provides a more convincing approach to the integration of the modern functions into trademark law. Regarding the latter point, the analysis revealed that trademark owners can in certain situations have a justified moral expectation to prevent third users from entering markets using their reputable mark. However, to avoid transforming misappropriation into a catch-all category, this moral expectation should be supported with economic considerations using a global appreciation test.

Hence, the paper found that continuing to rely on three independent rationales to protect modern trademark functions would essentially add complexity, impracticality and fragmentation to an area already muddled in its own complexity. Accordingly, to avoid this result, it was suggested that misappropriation should be the principal ground for extending trademark protection, and that harm resulting from blurring and tarnishment should act as an ancillary to free-riding claims. Despite entailing monopolistic elements, recognizing free-riding as a distinct theory for establishing trademark liability is likely to enhance the consistency of the law while integrating the modern functions into the scope of trademark protection. This approach avoids the development of modern trademark protection based on unjustified rationales which are very highly speculative. In addition, this approach is logical since in practice, the harm resulting from blurring, and particularly from tarnishment, renders both the moral and the economic case for free-riding more compelling. ${ }^{260}$

Open Access This article is licensed under a Creative Commons Attribution 4.0 International License, which permits use, sharing, adaptation, distribution and reproduction in any medium or format, as long as you give appropriate credit to the original author(s) and the source, provide a link to the Creative Commons licence, and indicate if changes were made. The images or other third party material in this article are included in the article's Creative Commons licence, unless indicated otherwise in a credit line to the material. If material is not included in the article's Creative Commons licence and your intended use is not permitted by statutory regulation or exceeds the permitted use, you will need to obtain permission directly from the copyright holder. To view a copy of this licence, visit http:// creativecommons.org/licenses/by/4.0/.

$\overline{260}$ See Red Plc v. WHG International Ltd [2011] EWHC 62 (Ch) at [133], para. 128. 


\section{References}

\section{Books and Articles}

Aaker D (1991) Managing brand equity. The Free Press, Mumbai

Akerlof GA (1980) Theory of social custom, of which unemployment may be a consequence. Q J Econ $84: 749$

Alexander M (2014) Realism. Stanford encyclopaedia of philosophy http://plato.stanford.edu/entries/ realism/. Accessed 25 June 2018

Anderson J (1983) The architecture of cognition. MA Harvard University Press, Harvard

Arneson R (1982) The principle of fairness and free-riders problems. Ethics 82:616

Austin GW (2008) Tolerating confusion about confusion: trademark policies and fair use. Ariz Law.Rev $50: 157$

Barnes D (2010) Free-riders and trademark law's first sale rule. Santa Clara Comput High Technol Law J 27(3):457

Basma D (2016) The nature, scope, and limits of modern trademark protection: a luxury fashion industry perspective. PhD Thesis, University of Manchester

Basma D (2021) Trademark protection versus freedom of expression: towards an expressive use defense in European trademark law. IPQ 3:206

Bedi S, Reibstein D (2020) Measuring trademark dilution by tarnishment. IND Law J 95:683

Beebe B (2006) A defence of the new federal trademark anti-dilution law. Fordham Intell Prop Media Entertain Law J 16:1143

Beebe B (2014) The suppressed misappropriation origins of trademark antidilution law: the Landgericht Elberfeld's Odol opinion and Frank Schechter's rational basis of trademark protection. In: Dreyfuss R, Ginsburg J (eds) Intellectual property at the edge: the contested contours of IP. Cambridge University Press, Cambridge

Beebe B, Germano R (2019) Testing for trademark dilution in court and the lab. Univ Chic Law Rev 86(3):611

Beebe B, Sunder M (2015) The luxury economy and intellectual property: critical reflections. OUP, Oxford

Bellaiche JM, Mei-Pochtler A, Hanisch D (2010) The new world of luxury: caught between growing momentum and lasting change. Boston Consulting Group. http://www.bcg.com/documents/ file67444.pdf. Accessed 24 Nov 2019

Benelux Trademark Act (1978)

Bird CR (2006) The impact of the Moseley decision on trademark dilution law. (May 17) http://papers. ssrn.com/sol3/papers.cfm?abstract_id=903003. Accessed 25 Oct 2019

Black's Legal Dictionary (2004) Unjust enrichment. 8th edn

Black's Law Dictionary (2009) 9th edn

Bomsel O (2014) Free-riding and luxury brands on the internet. IBR 7(2):60

Bone R (2006) Hunting goodwill: the history of the concept of goodwill in trademark law. BUL Rev $86: 547$

Bone R (2008) Schechter's ideas in historical context and dilution's rocky road. Santa Clara Comput High Technol Law J 24:469

Bradford L (2008) Emotion, dilution and the trademark consumer. Berkeley Technol Law J 23:1227

Brown S Jr (1948) Advertising and the public interest: legal protection of trade symbols. Yale Law J 57(7): 1116

Buccafusco C, Heald P, Wen B (2017) Testing tarnishment in trademark and copyright law: the effect of pornographic versions of protected marks and works. Wash Law Rev 94:341

Burberry Group Plc (2004) Annual report and accounts. 2004/05, 44

Burberry Group Plc (2005) Annual report and accounts. 2005/06, 47

Calboli I (2007) The sunset of quality control in modern trademark licensing. Am Univ Law Rev $57(2): 341$

Caleshu J (1964) The "free-ride" doctrine: unfair competition. Trademark infringement. Sriwij Law Rev 16(3):736

Callmann R (1942) He who reaps where he has not sown: unjust enrichment in the law of unfair competition. Harv Law Rev 55:595

Carbal L (2000) Introduction to industrial organisation. MIT Press, Cambridge 
Caroll B, Ahuvia A (2006) Some antecedents and outcomes to brand love. Springer Sci 17:79

Carter S (1992) Does it matter whether intellectual property is property? Chi-Kent Law Rev 68:715

Chiari C (2009) Everlasting luxury. The future of inaccessibility. Le Fonti

Cho S, Lee JL, Won J (2019) Empirical investigation of sports trademark dilution using contingent valuation methods. JSM 34(3):189

Chronopoulos A (2011) Determining the scope of trademark rights by recourse to value judgements related to the effectiveness of competition-the demise of the trademark use requirement and the functional analysis of trademark law. IIC 42:535

Chronopoulos A (2014) Legal and economic arguments for the protection of advertising value through trademark law. QMJIP 4(4):250

Cohen F (1935) Transcendental nonsense and the functional approach. Colum Law Rev 35:809

Coleman J (1992) Intellectual property and corrective justice. Y Law J 78:283

Corneo G, Jeanne O (1997) Snobs, bandwagons, and the origin of social customs in consumer behaviour. J Econ Behav Organ 32(2):333

Cunningham J, Cunningham S (2014) Sociology and social work. Learning Matters

Daily Mail (2008) The luxury brand with a chequered past, Burberry's shaken off its chav image to become the fashionistas favourite once more. Daily Mail, June http://www.dailymail.co.uk/femail/ article-1023460/Burberrys-shaken-chav-image-fashionistas-favourite-more.html. Accessed 16 Oct 2019

Davis F (1992) Fashion, culture and identity. Chicago University Press

Desai D (2018) The Chicago trap in trademark: the co-evolution of corporate, anti-trust and trademark law. Car Law Rev 37:552

Desai R, Lianos I, Waller S (2015) Brands, competition law and IP law. Cambridge University Press, Cambridge

Dinwondie G, Janis M (2007) Confusion over use: contextualise in trademark law. Iowa Law Rev 92:1597

Dogan S (2006) What is dilution anyway? Mich Law Rev First Impress 105:103

Dornis T, Wein T (2014) Trademark rights, comparative advertising, and the "perfume comparison lists" - an untold story of law and economics. Inst. für Volkswirtschaftslehre 3, 4. The fashion law, "LV \& the danger of over-exposure" (Fashion Law, 2013). http://www.thefashionlaw.com/?p= 1358. Accessed 16 Oct 2019

Dorsen H (1985) Satiric appropriation and the law of libel, trademark and copyrights: remedies without wrongs. BUL Rev 65:923

Dubois B, Laurent G, Czeller S (2011) Consumer rapport to luxury: analysing complex and ambivalent attitudes. Working paper, HEC Paris, Jouy-en-Josas http://www.hec.fr/var/fre/storage/original/ application/5ecca063454eb4ef8227d08506a8673b.pdf. Accessed 1 Dec 2019

Duncan SM (2010) Protecting nominative fair use, parody, and other speech-interests by reforming the inconsistent exemptions from trademark liability. Mich Law Rev 44(1):219

Elliot R (1997) Existential consumption and irrational desire. EJM 34(4):285

Elliot R, Wattamasuwan K (1998) Brands as resources for symbolic construction of identity. IJA 17(2): 131

Emerson P (2011) "I'm litigating it": infringement, dilution, and parody under the Lanham Act. North West J Technol Intell Prop 9(7):477

EUIPO (2020) Guidelines for examination of European Union trademarks: trademarks with reputation, Article 8(5) EUTMR. https://euipo.europa.eu/tunnel-web/secure/webdav/guest/document_library/ contentPdfs/trade_marks/draft-guidelines-wp-2020/part_c_opposition_section_5_trade_marks_ with_reputation_article_8_5_eutmr_en.pdf

Fhima S (2011) The Court of Justice's protection of the advertising function of trademarks-an (almost) sceptical analysis. JIPLP 6(5):325

Fisher W (2001) Theories of intellectual property, in new essays in the legal and political theory of property. In: Munzer S (ed) new essays in the legal and political theory of property. Cambridge University Press, Cambridge

Franklyn DA (2003) Beyond dilution: toward a comprehensive theory of the anti-free-riding impulse in American trademark law. Bepress Legal Series.Working Paper, 58 http://law.bepress.com/cgi/ viewcontent.cgi?article=1130\&context=expresso. Accessed 12 Dec 2019

Frischmann BM, Lemley M (2007) Spillover. 107 Colum. L. Rev. 257

Gangjee D (2013) Property in brands: the commodification of conversation, in property concepts in intellectual property law. In: Hower HR, Griffiths J (eds) 
Gervais D, Hokmes M, Kruse P, Perdue G (2013) Is profiting from the online use of another's property unjust? The use of brand names as paid search keywords. IP Law Rev 53:131

Gielen C (2014) Trademark dilution under European law. TMR 104:701

Gordon J (1993) A property right in self-expression: equality and individualism in the natural law of intellectual property. YLJ 102:1533

Gordon W (1992) On owning information: intellectual property and the restitutionary impulse. Va Law Rev 75:149

Griffiths A (2001) The impact of global appreciation approach on the boundaries of trademark protection. IPQ 4:326

Griffiths A (2007) The trade mark monopoly: an analysis of the core zone of absolute protection under Art. 5.1(a). IPQ 3:312

Griffiths A (2008) A law and economics perspective. In: Bentley D, Ginsburg (eds) Trademarks and brands; an interdisciplinary critique. Cambridge University Press, Cambridge

Handler M (2016) What can harm the reputation of a trademark? A critical re-evaluation of dilution by tarnishment. TMR 106:639

Hart HLA (1955) Are there any natural rights? Philos Rev 64:175

Harris R (1964) The real voice. Macmillan, Basingstoke

Holt D (1995) How consumers consume: a typology of consumption practices. J Consum Res 22:1

Hume D (1896) The treatise of human nature. L.A. Selby Biggie, Clarendon Press

Huntley J, Stephen F (1995) Unfair competition, consumer deception, and brand copying: an economic perspective. Int Rev Law Econ 15:443

Isaac B (2000) Brand protection matters. Sweet and Maxwell, Mytholmroyd

Kang J (2005) Trojan horses of race. Harv Law Rev 118:1489

Kapferer J (2015) Kapferer on luxury: how luxury brands can yet remain rare. Kogan Page, London

Kay MJ (2006) Strong brands and corporate brands. EJM 40(7/8):742

Keller KL (1999) Managing brands for the long run: brand reinforcement and revitalization strategies. Calif Manag Rev 41(3): 102

Keller KL, Aaker DA (1992) The effects of sequential introduction of brand extensions. J Mark Res 29:35

Kenneally ME (2015) Misappropriation and the morality of free-riding. Stan Technol Law Rev 19:289

Kenneally MK (2014) Intellectual property rights and institutions; a pluralist account. Ph.D Thesis, Harvard University

King S (1990) Brand building in the 1990s. JMM 7(1):3

Klieger R (1997) Trademark dilution: the whittling away of the rational basis for trademark protection. Univ Pittsburgh Law Rev 58:789, 801

Klosko G (1987) Presumptive benefit, fairness and political obligation. Philos Publ Aff 16:241

Kort P, Caulkins J, Hartl R, Feichtinger G (2006) Brand image and dilution in the fashion industry. J IFAC 42:1363

Kratzke W (1991) Normative economic analysis of trademark law. 21(2) University of Memphis Law Review, University of Memphis Legal Studies Research Paper No. 63. http://papers.ssrn.com/sol3/ papers.cfm?abstract_id=1702386. Accessed 20 Nov 2020

Kruger H (2014) Trademark and brand dilution: an empirical investigation. PhD Thesis, Stellenbosch University

Laan NV (2012) The use of trademarks in keyword advertising: developments in the CJEU and national jurisprudence. MPI for Intellectual Property and Competition Law Research Paper No. 12-06, 6 http://papers.ssrn.com/sol3/papers.cfm?abstract_id=2041936

LaFrance M (2011) Passing off and unfair competition: conflict and convergence in competition law. Mich St L Rev 1413

Landes W, Posner R (2003) Indefinitely renewable copyright. UCLR 70:471, 487

Langle E (2005) Pierre Cardin: fifty years of fashion and design. Thames and Hudson, London

Leaper C (2015) Everything you need to know about the Balmain X H\&M collaboration. MarieClaire. http://www.marieclaire.co.uk/news/fashion/550623/balmain-x-h-m-the-balmain-h-and-mcollaboration-in-pictures.html\#index=1. Accessed 7 Jan 2019

Leffer K (1981) Persuasion or information? The economics of prescription drug advertising. J Law Econ 24:46

Lemley M (1999) The modern Lanham Act and the death of common sense. YLJ 108:1687

Lemley M (2005) Property, intellectual property, free-riding. Texas Law Rev 83:1031

Lemley M, McKenna M (2010) Owning mark (eds). Mich L Rev 109:137 
Lemley M, McKenna M (2012) Is Pepsi really a substitute for Coke? Market definition in antitrust and IP. Geo Law J 100:2055

Locke J (1964) Two treatises of government. Cambridge University Press, Cambridge

Locke J (1993) Of property. In: Locke political writings

Manta M (2007) In search of validity: a new model for the content and procedural treatment of trademark infringement surveys. Cardozo Art Entertain Law J 24:1027

Marks R (1978) Trademark protection under the 'natural area of business expansion' doctrine. NotreDame Law Rev 53:869

Mars. Inc, Mars Petcare UK Unled, Mars Belguim NV v. Joseph Deters, Gedon Pet NV [2014] Commercial Court of Brussels (Chamber E)

McCabe KB (2000) Dilution-by-blurring: a theory caught in the shadow of trademark infringement. Fordham Law Rev 68:1827

McCarthy T (2010) McCarthy and unfair competition. 4th edn

McKenna M (2007) The normative foundation of trademark law. Notre Dame Law Rev 82:1839

McKenna M (2009) Testing modern trademark law's theory of harm. Iowa Law Rev 95:63

Meyers-Levy J (1989) The influence of a brand name's association set size and word frequency on brand memory. JCR 16:197

Morck R (1992) Internalization; an event study test. J Int Econ Law 33:41

Morrin M, Jacoby J (2000) Trademark dilution: empirical measures for an elusive concept. JPP \& M 19(2)

Morrin M, Lee GJ, Allenby GM (2006) Determinants of trademark dilution. JCR 33:248

Marketing 265

Moskin J (1993) Dilution law: at a crossroads? Dilution or delusion: the rational limits of trademark protection. TMR 83:122

Naser M (2007) Re-thinking the foundations of trademarks. Buff Intell Prop Law J 5(1):1

Ng-Loy W (2012) The sense and sensibility in the anti-dilution right. S Ac Law J 24:927

Nims H (1929) The law of unfair competition and trademarks. 3rd edn in Callmann (n. 232)

Nozick R (1974) Anarchy, state and utopia. Basic Books, New York

Okonkwo U (2007) Luxury fashion branding; trends, tactics, techniques. Palgrave Macmillan, London

Ostler C (2014) As Romeo Beckham stars in their new ad, how Burberry went from chic to chav to chic again (November). http://www.dailymail.co.uk/femail/article-2822546/As-Romeo-Beckham-starsnew-ad-Burberry-went-chic-chav-chic-again.html. Accessed 24 Nov 2019

Pattishall B (1977) The dilution rationale for trademarks - trademark identity protection, its progress and prospects. TMR 67:607

Port K (1994) The 'unnatural' expansion of trademark rights: is a federal dilution statute necessary? Seton Hall Leg J 18:433

Posner RA (1992) When is parody fair use? J Legal Stud 21:67

Prager EA (1996) The Federal Trademark Dilution Act of 1995: substantial likelihood of confusion. Fordham Intell Prop Media Entertain Law 7:121

Prescott P (1997) Has the Benelux trade mark law been written into the Directive? EIPR Rev 18:99

Rahmatian A (2005) Copyright and commodification. EIPR Rev 27:371

Rawls J (1955) Legal obligation and the duty of fair play (Sidney Hook ed 1964)

Rao V, Agarwal M, Daholoff D (2004) How is manifest branding strategy related to the intangible value of a corporation? JM 68:126

Reddy M, Terblanche N (2005) How not to extend your luxury. Accessed 23 Aug 2021

Ricketson S (1984) 'Reaping without sowing': unfair competition and intellectual property rights in Anglo-Australian law. UNSWLJ 7:1

Rierson SL (2012) The myth and reality of dilution. Duke Law Technol 11:213

Robinson A, Pratt G, Kelly R (2013) Trademark law: harmonization in the European Union: twenty years back and forth. Fordham Intell Prop Media Entertain Law 23:731

Sakulin W (2010) Trademark protection and freedom of expression: an inquiry into the conflict between trademark rights and freedom of expression under European law. Wolters Kluwer

Scassa T (2012) Trademarks worth a thousand words: freedom of expression and the use of the trademarks of others. Les Cahiers de droit 53(4):877

Schechter F (1927) The rational basis of trademark protection. HLR 40:813

Senftleben M (2008) The Tower of Babel - dilution concepts in international, US and EC trademark law. IIC 40(1):45

Sheff J (2013) Marks, morals and markets. Stanf Law Rev 65:761 
Sheinin B, Schmitt BH (1994) Extending brands with new product concepts: the role of category attribute congruity, brand affect, and brand breadth. J Bus Res 3(1):1

Silverstein M, Fiske N (2008) Trading up: why consumers want new luxury goods - and how companies create them. PORTFOLIO

Som A, Blanckaert C (2015) The road to luxury: the evolution, markets and strategies of luxury brand management. Wiley, New York

Spector HM (1989) An outline of a theory justifying intellectual and industrial property rights. EIPR 11:270

Spence HM (1996) Passing off and the misappropriation of valuable intangibles. Law Q Rev 112:472

Swann D, David T (1994) Dilution, an idea whose time has gone: brand equity as protectable property, the new/old paradigm. IPR 11:219

Swann J (2002) Dilution redefined for the year 2002. TMR 92:607

Terry A (1988) Unfair competition and the misappropriation of a competitor's trade values. MLR 51:296

The Fashion Law (2013) LV and the risk of overexposure. October http://www.thefashionlaw.com/louisvuitton-the-danger-of-over-exposure/. Accessed 1 Dec 2019

Timber S (1949) Trademarks, monopoly and the restraint of competition. Law Contemp Prob 14:323

Tran J (2002) Dilution by tarnishment: a case for vulgar humour. Intell Prop Law Bull 7:1

Tushnet R (2008) Gone in sixty milliseconds: trademark law and cognitive science. Texas Law Rev $86: 507$

Waldron J (1988) The right to private property. OUP, Oxford

\section{Statutes and Directives}

Council Directive (EU) 2015/2436 (EU)

Council Directive (EU) 2008/95 EC (EU)

The Lanham (Trademark) Act 1943 (USA)

\section{EU Case Law}

C-102/07 Adidas and Adidas Benelux [2008] ECR I-0000 ('Adidas II')

C-125/14 Iron v. Unilever [2015] ECLI:EU:C:2015:195. Opinion of Advocate General Wahl

C-17/06 Celine SARL v. Celine SA [2006] ECR I-0704

C-206/01 Arsenal Football Club v. Mathew Reed Case [2002] E.T.M.R. 19

C-206/01 Arsenal v. Reed [2002] E.T.M.R. 18. Opinion of AG Ruiz Colomer

C-228/03 Gillette Company v. Gillette Group Finland [2005] E.C.R I-2337

C-229/03 Gillette Co v. L-A Laboratories Oy [2005] FSR 37

C-251/97 Sabel Bv v. Puma [1997] ECR I-06191

C-252/07 Intel Corp Inc v. CPM United Kingdom Ltd [2008] ECR I-8823

C-252/12 Specsavers International Healthcare Ltd. v. Asda [2013] Bus.L.Rev. 1277, [2013] ECWA Civ. 494

C-253/07 Intel Corporation Inc. v. CPM United Kingdom Limited [2008] ECR I-08823. Opinion of AG Sharpson

C-375/97 General Motors Corp v. Yplon SA [1999] ECR I-5421

C-39/97 Canon Kabushiki Kaisha v. MGM [1999] R.P.C. 117

C-408/01 Adidas-Salomon AG. v. Fitness world Trading Ltd. [2003] E.T.M.R. 91. Opinion of AG Jacobs C-487/07 L'Oréal SA v. Bellure NV [2009] ECLI 378

C-85/16 Tsujimoto v. European Intellectual Property Office [2018] ECLI:EU:C:2018:349

Intel Corp v. Sihra [2003] EWHC 17

Interflora v. Marks and Spencer PLC [2013] EWHC 1291 (Ch)

R 2124/2010-1 LV [2011]

R 297/2011-5 Karelia Tobacco Company Inc. v. Basic Trademark SA (KAPPA) [2012] Unreported

R 240/2004-2 WWRD Ireland IPCo LLC v. Assembled Investments Ltd [2010] Unreported

R-283/1993-3 Hollywood S.A.S. v. Souza Cruz S.A. [2002] E.T.M.R. 705

R-318/2016-5 Dulces v. Conservas HELIOS, S.A. v. Guangzhou Petshine Pet Products Co. [2016] 
R-403/2008-1 Emotions Coffe Cola v. Coca Cola et al [2009]

R-417/2008-1 Space NK v. SA Spa Monopole [2009] OHIM First Board of Appeal

R-657/2009 Bambuddha v. Buddha Bar [2010]

T-215/03 SILGA AG v. OHIM [2007] ECR-II-00711

T-570/10 RENV Environmental Manufacturing v. Office for Harmonization in the Internal Market (OHIM)[2015] ECLI:EU:T:2015:76

T-570-10 Environmental Manufacturing v. Office for Harmonization in the Internal Market (OHIM)[2012] E.T.M.R. 54

T 61/16 Coca Cola v. EUIPO [2017] ECLI:EU:T:2017:877

T-624/13 The Tea Board v. OHIM [2015] EU:T:2015:743

T-67/04 Spa Monopole, Compagnie Fermiere de Spa SA/NV v. OHIM [2005] ECLI:EU:T:2005

\section{UK Case Law}

Argos Ltd v. Argos Systems Inc [2017] Bus. L. Rev. 958

Azumi Ltd v. Zuma Choice Pet Products [2017] EWHC 45

British Sky Broadcasting Group Plc v. Microsoft Corp [2013] EWHC 1826 (Ch)

Cadbury Schweppes Pty Ltd v. The Pub Squash [1981] A.L.J.R. 333

Champagne Louis Roederer v. Gracia [2017] EWHC 289 (Ch)

Jack Wills Ltd v. House of Fraser (Stores) Ltd [2014] EWHC 110 (Ch)

$L \&$ D S.A. v. In the Matter of An Application for Invalidity No. 16182 [2015]

L'Oréal v. Bellure [2010] EWCA Civ 535

Natural Instinct Ltd v. Natures Menu Ltd [2020] E.T.M.R. 34

Odol, Landgericht Elberferd [1925] NJW 502

PlanetArt LLC v. Photobox Ltd [2020] E.T.M.R. 35

Premier Brands UK v. Typhoon Europe Ltd [2000] E.T.M.R. 1071

Red Bull GmbH v. Sun Mark Ltd and Sea Air \& Land Forwarding Ltd [2012] EWHC 1929 (Ch)

Red Plc v. WHG International Ltd [2011] EWHC $62(\mathrm{Ch})$ at [133]

Sky Plc v. Sky Kick UK Ltd [2018] EWHC 166 (Ch)

Skyscape Cloud Services Ltd v. Sky Plc [2016] F.S.R. 5

Taittinger v. Allbev Ltd. [1993] F.S.R. 641

The Dimple Case [1985] GRUR 550

Whirlpool Corp v. Kenwood Ltd [2009] EWCA Civ 353

\section{US Case Law}

Allied Maintenance Corp. v. Allied Mechanical Trades Inc. 369 N.E.2d 1162 (N.Y. 1977)

Dresser-Rand v. Virtual Automation Cp. 361 F.3d at 839 (2004)

Hermes Int'l v. Lederer de Paris Fifth Ave., Inc. 219 F.3d 104, 108 (2d. Cir. 2000)

Int'l News Serv. v. Associated Press 248 U.S. 215 (1918)

J. I. Case Plow Works v. J. I. Case Threshing Machine Co. [1916] 162 Wis. 185, 201, 155 N. W. 128

Mishawaka Rubber \& Woolen Mfg. Co. v. S. S. Kresge 62 Sup. Ct. 1022, 1024, 1025 (1942)

National Basketball Association v. Motorola Inc. 105 F.3d 841(2d Cir. 1997)

Onassis v. Christian Dior-New York, Inc. 472 N.Y.S.2d 254, 261 (N.Y. Sup. Ct. 1984)

Smith v. Chanel, 402 F.2d 526 (9th Cir. 1968)

Ty Inc. v. Perryman, 306 F.3d 509 (7th Cir. 2002)

United Lace \& Braid Mf. Co. v. Barthels Mfg. Co. 221 F. 456, 461. (E.D.N.Y. 1915)

Mosely v. Victoria Secret Catalogue 537 U.S. 418 (2003)

Publisher's Note Springer Nature remains neutral with regard to jurisdictional claims in published maps and institutional affiliations. 